\title{
Spatio-Temporal Variation in Rainfall Erosivity over Jordan Using Annual and Seasonal Precipitation
}

\author{
Y. Farhan1, S. Alnawaiseh ${ }^{2}$ \\ ${ }^{1}$ The Trustee Council of Al-Ahliyya University, Amman, Jordan \\ ${ }^{2}$ Geography Department, Yarmouk University, Irbid, Jordan \\ Email: wjetfan47962@gmail.com
}

How to cite this paper: Farhan, Y. and Alnawaiseh, S. (2018) Spatio-Temporal Variation in Rainfall Erosivity over Jordan Using Annual and Seasonal Precipitation. Natural Resources, 9, 242-267. https://doi.org/10.4236/nr.2018.96016

Received: May 19, 2018

Accepted: June 24, 2018

Published: June 27, 2018

Copyright $\odot 2018$ by authors and Scientific Research Publishing Inc. This work is licensed under the Creative Commons Attribution International License (CC BY 4.0).

http://creativecommons.org/licenses/by/4.0/

(c) (i) Open Access

\begin{abstract}
The objective of this research is to estimate the annual and seasonal rainfall erosivity over Jordan based on three different regression models. Readily available annual and seasonal precipitation data with long records (40 - 53 years) pertaining to 40 weather stations were utilized to estimate rainfall erosivity. The spatial distribution of rainfall erosivity over Jordan is controlled largely by morphological (relief) and climatic factors. The lowest $R$-values (28 MJ $\mathrm{mm} \cdot \mathrm{ha}^{-1} \cdot \mathrm{h}^{-1} \cdot \mathrm{yr}^{-1}$ ) are found in the arid zone, where the average annual rainfall is below $100 \mathrm{~mm}$, whereas the highest $R$-values are found in the northern highlands ( $505 \mathrm{MJ} \mathrm{mm} \cdot \mathrm{ha}^{-1} \cdot \mathrm{h}^{-1} \cdot \mathrm{yr}^{-1}$ ) where the average annual rainfall approaches $650 \mathrm{~mm}$. The correlation between annual and seasonal precipitation $(\mathrm{mm})$ and annual erosivity exhibits a very strong relationship ( $R$ varies from 0.964 to 1.0 , and all correlations are significant at 0.01 level [2-tailed test]). Moderate positive correlations were achieved between latitude $(\mathrm{N})$ and the mean annual/seasonal precipitation ( $R$ ranges from 0.407 to 0.642 , and all correlations are significant at 0.01 level [2-tailed test]). Spatial differences observed in erosivity, afforded a substantial source of information and maps for predicting erosion in Jordan. According to the present analysis, two parameters proved to be useful to predict rainfall erosivity on a national level. These parameters are the average annual precipitation, and latitude.
\end{abstract}

\section{Keywords}

Rainfall Erosivity, Regression Models, Pearson Correlation, Annual and Seasonal Precipitation, Soil Erosion

\section{Introduction}

Soil erosion in dry-Mediterranean, semi-arid, and arid zones of Jordan is attri- 
buted mainly to recurrent intense rainstorms. The rainfed agricultural region has experienced severe and widespread soil erosion including sheet, splash, rill and gully erosion, and landslide activity. Erosion of top soil leads to declining soil fertility and productivity, hence restricting the area of potential future agriculture. Soil erosion is not a recent problem in the country; it was active prehistorically and historically in the rainfed highlands of Jordan. It is stated that accelerated soil erosion, intense agriculture, and agricultural terraces were predominant over the denudational slopes of the Levantine highlands including Jordan since the Iron Age [1]. Cordova [2] also concluded that the destruction of vegetation cover caused high soil loss rates since the Neolithic and Chalcolithic periods. Indicators of soil erosion and the existence of agricultural terraces revealed that the highlands of Jordan experienced severe soil erosion at least since the Nabatean period 3000 years ago, and intensive exploitation of land resources, continuous land use/land cover changes, and rapid population growth $(2.7 \%$ per year) since the 1950's maximized soil degradation.

Several investigations and reports have been carried out on soil erosion in Jordan since the 1960's. The Natural Resources Authority (NRA) [3] reported that heavy rainstorms initiated severe erosion and the resultant sediments filled the East Ghor canal (King Abdullah canal) completely. McDonald Partners and Hunting Technical Services LTD [4] estimated soil erosion loss for all watersheds in Jordan at 1.328 million tons $\cdot \mathrm{yr}^{-1}$, which indicates that top productive soil is eroded at a rate of $0.14 \mathrm{~cm}$ annually. The soil erosion map of the FAO et al. [5] classifies most of the country within $10-50$ tons $\cdot \mathrm{ha}^{-1} \cdot \mathrm{yr}^{-1}$. Repetitive heavy rainstorms were reported since the 1940 's, and it was concluded that rainfall intensity ranges from 2 to $6.6 \mathrm{~mm} \cdot \mathrm{yr}^{-1}$ [6] [7] [8]. Further, exceptional heavy rainstorms were also reported in southern Jordan by the Central Water Authority [9], and Schick [10] [11] [12], Murphy [13], Al-Qudah [14], Farhan and Anbar [15]. Schick [10], for example, estimated that the average $4 \mathrm{hr}$ rainfall storm yielded an intensity of $16 \mathrm{~mm} / \mathrm{hr}$. According to Murphy [13], rainfall intensities were predicted to reach up $120 \mathrm{~mm} \cdot \mathrm{hr}^{-1}$. Such high rainfall intensities caused serious soil erosion loss and high sediment yield in streams/wadis draining to the Jordan Rift. Using the AGNPS erosion model, Al-Sheriadeh et al. [16] estimated that the annual sediment yielded at King Talal Reservoir (Zerqa River) at 2.9 $\mathrm{Mm}^{3} \cdot \mathrm{yr}^{-1}$. Moreover, Al-ansari and Knutsson [17] reported that W. Alarab Dam (northern Jordan) would be filled with sediments within 38 years. Additionally, the predicted average annual sediment yield for W. Wala, based on a SWAT model, was 140.78 tons. $\mathrm{yr}^{-1}(2000-2007)$ and 123.1 tons. $\mathrm{yr}^{-1}$ (2008-2020) respectively [18]. Likewise, the predicted annual sediment yield for W. Mujib was 341.887 tons $\cdot \mathrm{yr}^{-1}$ for the period 2007-2020 [19]. The estimated soil erosion loss for Wadi Kufranja [20] and W. Kerak [21] using the RUSLE model, denoted that continuous deterioration of top productive soil, and high soil erosion rates seriously endangered W. Kufranja Dam (northern Jordan), and the proposed dam of W. Kerak (southern Jordan). 
In situ field measurements of soil erosion were carried out in the dry-Mediterranean (Salt, W. Kufranja, and Jerash areas), semi-arid (the Muwaqar area), and arid (Azraq area) climate zones of Jordan. Measuring instruments were installed on small plots of varied environmental conditions, i.e., farming practice and the existence or absence of conservation measures i.e., tillage fields, fallow land, terraced fields, gradient, slope form and aspect [22]. The measured splash erosion for the dry-Mediterranean plots ranges from $3 \mathrm{ton} \cdot \mathrm{ha}^{-1} \cdot \mathrm{yr}^{-1}$ to 21.5 ton $\cdot \mathrm{ha}^{-1} \cdot \mathrm{yr}^{-1}$ [23] [24] [25]. Likewise, the measured splash erosion for the semi-arid plots varies from 2.59 to $16.3 \mathrm{ton} \cdot \mathrm{ha}^{-1} \cdot \mathrm{yr}^{-1}$ [26], and for the arid sites, it ranges from 2.8 to $7.39 \mathrm{ton} \cdot \mathrm{ha}^{-1} \cdot \mathrm{yr}^{-1}$ [27]. By contrast, the measured runoff erosion ranges from 0.581 to 2.282 ton $\cdot \mathrm{ha}^{-1} \cdot \mathrm{yr}^{-1}$ for the dry-Mediterranean plots, $1.05 \mathrm{ton} \cdot \mathrm{ha}^{-1} \cdot \mathrm{yr}^{-1}$ for the semi-arid sites, and $0.14 \mathrm{ton} \cdot \mathrm{ha}^{-1} \cdot \mathrm{yr}^{-1}$ for arid plots [23] [26] [27]. In the Shawbak-Wadi Musa area (southern Jordan), field measurements of soil erosion were performed using pegs and field splash cups. Soil erosion rates based on pegs range from 0.873 and $1.24 \mathrm{~mm} \cdot \mathrm{yr}^{-1}$, whereas the measured splash erosion for the same sites varies from 1.39 to $30.15 \mathrm{ton} \cdot \mathrm{ha}^{-1} \cdot \mathrm{yr}^{-1}$ [28]. Continuous human interventions, including the expansion of agriculture on steep slopes, woodland cutting and continuous over grazing, progressive land fragmentation, rapid urbanization, and agricultural intensification are the main triggering factors underlying soil degradation in the rainfed highlands of Jordan [29]. It is obvious that serious soil erosion loss and high sediment yield rates are predominant in Jordan, and since soil loss data is inadequate for soil conservation planning, an estimation of rainfall erosivity ( $R$-factor) from available rainfall data is of high priority, and can be used as an indicator of potential erosion risk, water resources planning, and watershed management. The $R$-factor in this context is considered a major input parameter for assessing soil erosion modeling using the universal soil loss equation (USLE) and the revised USLE (RUSLE) models. Information on rainfall erosivity can be calculated and employed as an indicator of the potential erosion risk in the country.

Rainfall erosivity is a numerical depiction of the potential that soil can be eroded by rainfall. It represents a key parameter for USLE and RUSLE modeling in soil erosion [30]. Several attempts have been carried out to estimate rainfall erosivity on a national scale. In this regard, India [31] [32] and Korea [33] [34] are the best examples. Recent applications of the rainfall erosivity parameter were extended beyond soil erosion modeling, sediment yield prediction, and water quality modeling. It was concluded recently that the accurate estimation of rainfall erosivity may supplement better modeling results [35]. According to the RUSLE model, soil loss from a cultivated field is directly proportional to a rainstorm parameter, if other factors remain constant. $R$-factor (or EI 30) in RUSLE is described as the "long-term average of the product of total storm kinetic energy (E) and the maximum intensity (I 30) for storm events" [35] [36] [37]. Such relationships help to quantify the impact of rain drops over a cultivated field and the rate of runoff associated with a storm event. Consequently, it is essential to employ rainfall data (Pluviograph data) to estimate the maximum 
30 min rainfall intensities for individual storms and heavy rainstorm events. It is recommended that rainfall data for at least 20 years are required to calculate rainfall erosivity for a given watershed, region, or on a national scale using the developed annual regression models, which proved to be sufficient to estimate long-term annual mean rainfall erosivity for RUSLE modeling. Annual rainfall data are available in Jordan at a reasonable spatial and temporal coverage with long records ( $>40$ years). The estimated rainfall erosivity values coupled with the iso-erodent maps are considered a first approximation of rainfall erosivity in Jordan, and it can be utilized as an efficient tool for future soil conservation. Regression-based models were developed to estimate the mean annual rainfall erosivity; i.e., [32] [38]-[46]. Most of these simplified models are similar in that they utilized annual rainfall data, and each model was calibrated and optimized for aspecific area or region and included site specific coefficients [36]. Although these annual regression models are apparently oversimplified for the actual variation of rainfall erosivity, the estimated $R$-values are also generally rough estimates [46]. In the present investigation, three regression models were employed to estimate $R$-values in Jordan. Such estimation techniques showed a high and significant correlation between rainfall erosivity and mean annual rainfall at watershed, regional, and national levels (i.e. [36] [38] [39] [40] [47]-[55]. Lo et al. [39], for example, reported a high correlation between mean annual rainfall and rainfall erosivity in Hawaii. Similarly, Jung et al. [38] concluded that a strong correlation was found between rainfall erosivity and annual rainfall over Korea. Goovaerts [40] also stated that the annual erosivity was positively correlated with altitude; he then included this parameter by utilizing DEMs in mapping rainfall erosivity in the Algarve region (southern Portugal). Furthermore, several studies carried out worldwide reported a high correlation between $R$-values and soil loss (i.e., [49] [54] [55] [56] [57] [58].

The objectives of the present study are:

1) Estimate rainfall erosivity using three different linear equations, and to assess the spatial distribution of annual and seasonal rainfall erosivity over the bio-climatic zones of Jordan.

2) Analyze the relationship between annual precipitation, rainfall erosivity data generated based on the three different models, and other site (weather stations) parameters (i.e., altitude [m], latitude and longitude).

3) Compare the resultant maps which illustrate the spatial distribution of annual and seasonal rainfall erosivity based on the three regression equation.

\section{Study Area}

The study area comprised all land areas of Jordan (hereafter Jordan). The target area lies between $29^{\circ} 11^{\prime} \mathrm{N}$ and $33^{\circ} 22^{\prime} \mathrm{N}$ and $18^{\circ} 39^{\prime} \mathrm{E}$ and $19^{\circ} 34^{\prime} \mathrm{E}$, covering 88,778 $\mathrm{km}^{2}$. It is located $80 \mathrm{~km}$ east of the Mediterranean (Figure 1). Elevations in the country range from $1750(\mathrm{~m})$ a.s.l (Jebel Rum, southern Jordan) to -431 (m) b.s.l opposite the outlet of W. Mujib at the Dead Sea. Jordan is rather homogeneous 


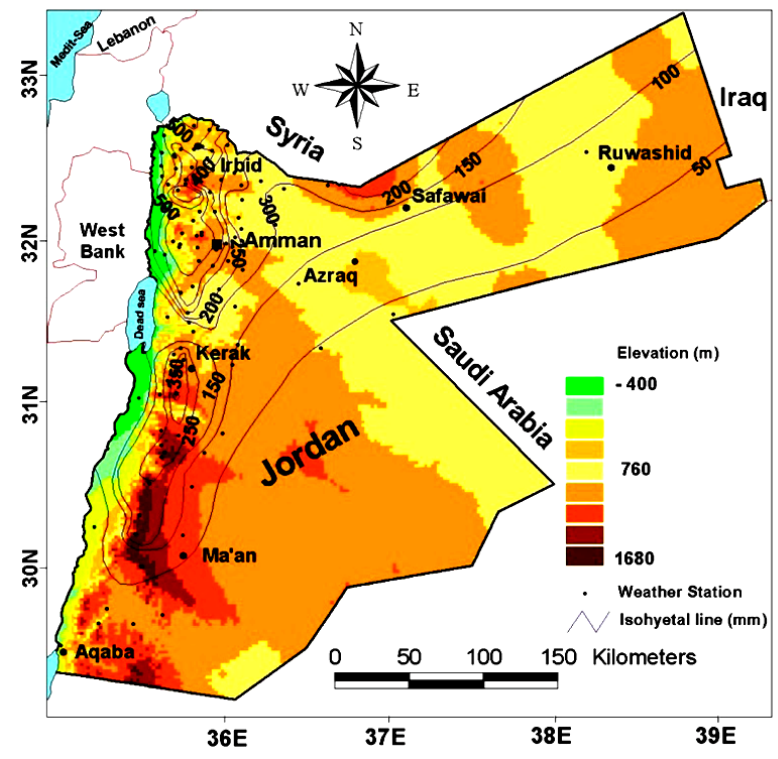

Figure 1. The study area-Jordan.

in terms of Koppen climatic zones [59]. BW class (arid) comprises $95 \%$ of the entire area, with a hot arid climate and winter precipitation, Whereas the semi-arid zone constitutes $4.7 \%$ of the country with a hot steppe climate and winter precipitation. The dry-Mediterranean climate accommodates only $0.3 \%$ of the total area. It is characterized by warm temperatures, a rainy winter climate, and dry and hot summers. Mean annual rainfall ranges from $638 \mathrm{~mm} \cdot \mathrm{yr}^{-1}$ in the Ajlune area in the northern highlands, to $37 \mathrm{~mm} \cdot \mathrm{yr}^{-1}$ at Aqaba in the south. $95 \%$ of the precipitation falls from November to March (70\% in December-February). Winter monthly temperatures of $2^{\circ} \mathrm{C}-5^{\circ} \mathrm{C}$ are recorded in the northern highlands, and $2^{\circ} \mathrm{C}-7^{\circ} \mathrm{C}$ for the arid south, east, and the Ghor. Summer months average $18^{\circ} \mathrm{C}-25^{\circ} \mathrm{C}$ in the highlands, with summer month temperatures reaching $40^{\circ} \mathrm{C}$ in the Badia. Frost-days number 5 - 15 per year [60]. Estimation of rainfall erosivity is of paramount importance for soil erosion assessment. $R$-values represent an indicator of rainfall aggression, and depend on both rainfall energy, raindrop size distribution, and kinetic energy (E), and the intensity of rainstorm event [50]. Rainfall in Jordan is characterized by a great spatial and temporal variability and often marked by high intensity. Thus, high intense rainstorms are common in both the northern and southern highlands, and in the eastern and southern arid zones. High rainfall intensity occasionally has caused severe flash-flooding and landslides with a large sediment load [15]. Most of the highland areas in central and northern Jordan have 20 to 50 rainy days/year. The amount of rainfall on any rainy day varies from $0.1 \mathrm{~mm}$ to a maximum of 150 $\mathrm{mm}$. Several days can receive precipitation ranging between $20-80 \mathrm{~mm}$ [60]. The characteristics of rainstorm events affect rainfall erosivity, which increases with a greater occurrence of a few high intensity rainstorms.

With reference to geological characteristics, Jordan lies across the northern 
rim of the great African-Arabian Pre-Cambrian shield [61]. In southwestern Jordan, part of the Nubo-Arabian shield was exposed, and is characterized by Pre-Cambrian granite, metamorphic rocks, and some occurrences of upper Proterzoic sedimentary rocks. Cambrian, Ordovician, and Silurian Sandstone of continental and marine origin with a maximum thickness of $1800 \mathrm{~m}$ conformably overlie the Precambrian basement complex. Most of southeastern and central Jordan is considered a zone of inter-fingering sedimentary rocks of continental, littoral, and neritic origin. Many stratigraphic unconformities persist. The total thickness of sedimentary strata is $2000-3000 \mathrm{~m}$, but it exceeds $4000 \mathrm{~m}$ in Al-Jafr basin (south-central Jordan), and $5000 \mathrm{~m}$ in the Azraq-W. Sirhan basin [62]. In northwestern Jordan, the total thickness of the sedimentary rocks above the Pre-Cambrian basement is about $7000 \mathrm{~m}$. In the Dead Sea area of the W. Araba-Jordan Rift, continuing structural subsidence resulted in accumulation of sedimentary rocks as much as $10,000 \mathrm{~m}$ thick. The crustal movements affecting Jordan since the Cambrian were gentle regional tilting, and a combination of faulting, block folding, and subsidence. From early Miocene to historical times, six basaltic flows occurred and were separated from each other by $5 \mathrm{~m}$ of fossil soils, red clay beds, and fossil weathered basalt surfaces [62].

The terrain in Jordan is morphologically varied. Thus, distinctive major geomorphological units can be recognized: the southern inselberg landscape is associated with large structural depressions. Here, the Pre-Cambrian granites are exposed, and overlain by Paleozoic and Mesozoic sandstone. The faulted-denudational block east of the rift is the second unit. It extends for 370 $\mathrm{km}$ from the Gulf of Aqaba to Lake Tiberias. The terrain slopes gently towards the central plateau in the east, while slopes are steep to very steep towards the Rift. Due to repeated subsidence of the Dead Sea, the westward drainage of the faulted block has been rejuvenated frequently. Thus, streams have cut further eastward into the central plateau, capturing additional areas of drainage to the Rift [61]. The central plateau of Jordan falls to flat, wide southeast-striking basins, namely Al-Jafr, Azraq, W. Al-Sirhan basins. Gently dipping limestone, marl, and chert beds (Upper Cretaceous and Lower Tertiary) are partly covered by weathered scree/debris. The elevations of the central plateau range from 850 $\mathrm{m}$ (Al-Jafr basin), to $1000 \mathrm{~m}$ to the north, and $>1500 \mathrm{~m}$ to the south at the escarpment of Ras en Naqb. The central part of Al-Jafr basin is an extensive mudflat $\left(240 \mathrm{~km}^{2}\right)$. Hundreds of square kilometers of the central plateau are covered by desert pavement consisting of wind-eroded chert residue, the flint-strewn "Hamada" desert. Extensive western drainage areas have been captured for the Rift by headward erosion of the W. Mujib, W. Kerak, W. Hasa, and W. Dana drainage systems. The basalt of several flows occupied what is termed "the northern plateau basalt". This major geomorphological unit has been cracked by insolation and broken into boulder/block fields of different sizes. The basalt shield is gradually lowered from $1100 \mathrm{~m}$ of elevation at the Syrian-Jordanian border in the north, to $550 \mathrm{~m}$ close to $\mathrm{W}$. Al-Sirhan. The northeastern plateau 
represents a monotonous peneplained landscape extending eastward across the Iraqi border. Here, the drainage pattern follows zones of structural weakness-mainly north-northwest and east-northeast [62]. The Jordan River-Dead Sea-W. Araba Rift constitutes a narrow depression that extends $370 \mathrm{~km}$ from the Gulf of Aqaba in the south, to Lake Tiberias in the north. Unconsolidated sediments (Miocene, Pliocene, and of Quaternary age) occupy most of the Rift floor along with extensive alluvial fans at the eastern and western borders of the Rift. Minor sand forms cover limited parts of W. Araba.

\section{Materials and Methods}

The most popular regression model employed to estimate the annual rainfall erosivity is the equation developed by Renard and Freimund [48], which is as follows:

$$
R=38.5+0.35 P
$$

where $R$ is rainfall erosivity (MJ $\mathrm{mm} \cdot \mathrm{ha}^{-1} \cdot \mathrm{h}^{-1} \cdot \mathrm{yr}^{-1}$ ) and $P$ is the mean annual rainfall $\left(\mathrm{mm} \cdot \mathrm{yr}^{-1}\right)$. This equation is known in Asia as the El-Swaify equation [36] [41]. This equation is considered an appropriate estimator of rainfall erosivity in tropical and subtropical climate regions [63]. Several researchers adopted this equation to estimate rainfall erosivity in countries including Thailand, Indonesis, Myanmar, and Philippines [64] [65] [66] [67]. Similarly, Singh et al. [32] elaborated an annual and seasonal rainfall erosivity equation to predict soil loss in India, which was widely used in estimating annual and seasonal rainfall erosivity on national, regional, and watershed levels in India; i.e., [68]. Thus, Equations (2) and (3) have been used for estimating annual and seasonal $R$ factors in the Indian context:

$$
\begin{gathered}
R a=79+0.363 P \\
R s=50+0.389 S P
\end{gathered}
$$

where:

Ra: mean annual rainfall erosivity $\left(\mathrm{MJ} \mathrm{mm} \cdot \mathrm{ha}^{-1} \cdot \mathrm{h}^{-1} \cdot \mathrm{yr}^{-1}\right)$;

$P$ : average annual precipitation $\left(\mathrm{mm} \cdot \mathrm{yr}^{-1}\right)$;

$R s$. the seasonal $R$ factor;

$S P$ : the average seasonal precipitation $\left(\mathrm{mm} \cdot \mathrm{yr}^{-1}\right)$.

Recently, Eltaif et al. [42] investigated the spatial distribution of annual rainfall erosivity in part of northern Jordan. They adopted a simplified procedure to correlate erosivity factor $R$ values in both the universal soil loss equation (USLE) and revised universal soil loss equation (RUSLE) with the annual rainfall amount or modified Fournier Index $\left(F_{\mathrm{mod}}\right)$. Rainfall data pertaining to 18 weather stations covering part of northern Jordan was utilized to predict $R$ values. A good fit was achieved between $R$ values and the mean annual precipitation $P$.

$$
R=23.61 \times \mathrm{e}^{0.0048 P+0.35 P}
$$

where: $R$ is the annual mean rainfall erosivity $\left(\mathrm{MJ} \mathrm{mm} \cdot \mathrm{ha}^{-1} \cdot \mathrm{h}^{-1} \cdot \mathrm{yr}^{-1}\right)$ and, $P$ is average annual precipitation $\left(\mathrm{mm} \cdot \mathrm{yr}^{-1}\right)$. 
Eltaif et al. [42] attributed the differences in $R$ values between the weather stations in western and eastern parts of northern Jordan, to the differences in precipitation, rainfall intensity, and the monthly distribution of rainfall. Moreover, they suggested that although the pattern of rain distribution was almost the same regardless of rainfall amount, which implied that rainfall amount and intensity were more important rainfall parameters than the monthly distribution in contributing to erosivity. More crucially, the equations elaborated by Renard and Fremund [48] can be comfortably accommodated with rainfall erosivity data of northern Jordan. Thus, the proposed equation of Eltaif et al. [42] shows sufficient reliability, and it could be more applicable for prevailing rainfall conditions in Jordan with respect to other equations developed elsewhere. In the present investigation, the authors applied the three regression equations mentioned earlier to estimate rainfall erosivity.

Three regression models were used to estimate annual and seasonal rainfall erosivity (MJ $\left.\mathrm{mm} \cdot \mathrm{ha}^{-1} \cdot \mathrm{h}^{-1} \cdot \mathrm{yr}^{-1}\right)$ over Jordan using mean annual $\left(\mathrm{mm} \cdot \mathrm{yr}^{-1}\right)$ and mean seasonal precipitation ( $\mathrm{mm}$ ) [32] [41] [42]. The database consists of 40 selected rainfall stations which reasonably cover the Köppen climatic zones of Jordan (Figure 2). The length of rainfall record ranges between 41 to 53 continuous years. The data represent the official reliable records of the Ministry of Water and Irrigation (MWI) [69]. Other information obtained from the MWI for each weather station is: mean annual and monthly precipitation (mm), altitude $(\mathrm{m})$, Latitude $(\mathrm{N})$, Longitude (E), and length of record (Years) (Table 1). Regression analysis was performed to evaluate the interactive relationship between annual precipitation and erosivity (calculated based on the three regression equations), annual and seasonal precipitation $(\mathrm{mm})$, and $R$-values against elevation $(\mathrm{m})$. The extent to which site parameters (i.e., altitude $(\mathrm{m})$, longitude $(\mathrm{E})$,

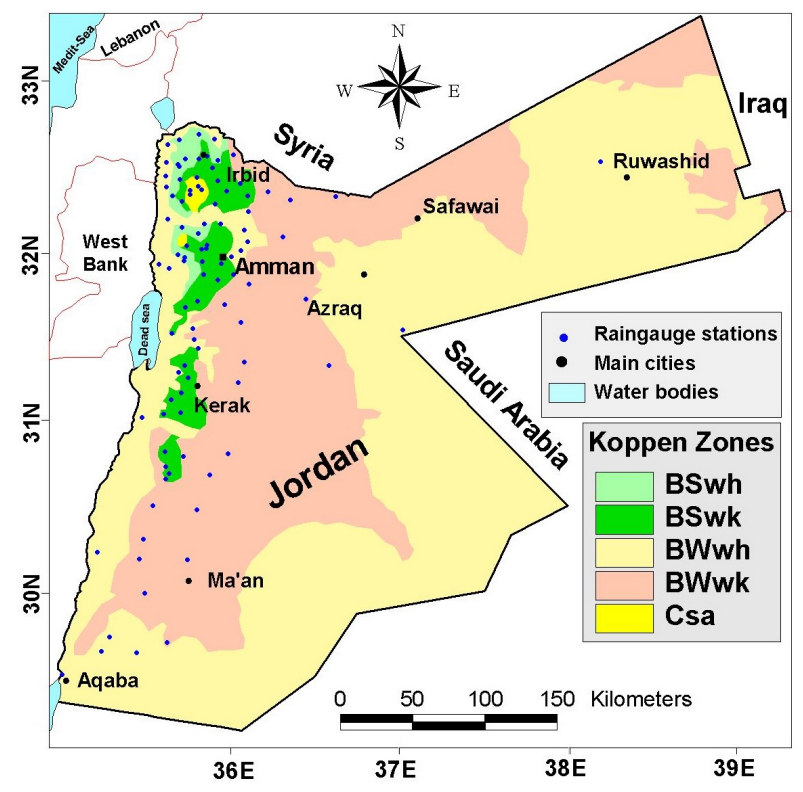

Figure 2. Climate Zones in Jordan (according to Köppen). 
Table 1. Annual and seasonal rainfall, and climatic zone, of the selected rainfall stations.

\begin{tabular}{|c|c|c|c|c|c|c|c|c|c|}
\hline $\begin{array}{l}\text { Station } \\
\text { Name }\end{array}$ & $\begin{array}{l}\text { Longitude } \\
\text { (E) }\end{array}$ & $\begin{array}{l}\text { Latitude } \\
\text { (N) }\end{array}$ & $\begin{array}{l}\text { Elevation } \\
\text { (m) }\end{array}$ & $\begin{array}{l}\text { Climate } \\
\text { Zone } \\
\text { (Koppen) }\end{array}$ & $\begin{array}{l}\text { Years of } \\
\text { Record }\end{array}$ & $\begin{array}{c}\text { Mean } \\
\text { f Annual } \\
\text { Rainfall } \\
(\mathrm{mm})\end{array}$ & $\begin{array}{c}\text { Autumn } \\
\text { Rainfall } \\
(\mathrm{mm})\end{array}$ & $\begin{array}{c}\text { Winter } \\
\text { Rainfall } \\
(\mathrm{mm})\end{array}$ & $\begin{array}{c}\text { Spring } \\
1 \text { Rainfall } \\
(\mathrm{mm})\end{array}$ \\
\hline Kufr Saum & 35.81524 & 32.68787 & 455 & BSwh & 51 & 518 & 60 & 326 & 132 \\
\hline Kharja & 35.90670 & 32.66142 & 455 & BWwh & 46 & 457 & 52 & 298 & 107 \\
\hline Um Qeis & 35.69679 & 32.65386 & 360 & BSwh & 46 & 474 & 65 & 318 & 104 \\
\hline Baqura AGR & 35.63059 & 32.62692 & -200 & BWwh & 46 & 390 & 57 & 245 & 88 \\
\hline Ramtha & 36.01725 & 32.56787 & 520 & BWwk & 51 & 281 & 34 & 185 & 73 \\
\hline Irbid & 35.86394 & 32.55909 & 585 & BSwk & 44 & 414 & 55 & 253 & 105 \\
\hline Rwaished & 38.19678 & 32.52694 & 755 & BWwh & 47 & 75 & 14 & 37 & 28 \\
\hline Gumaim & 35.69078 & 32.51163 & 375 & BSwh & 41 & 460 & 65 & 336 & 125 \\
\hline $\begin{array}{c}\text { Deir Abi } \\
\text { Said }\end{array}$ & 35.69939 & 32.49749 & 330 & BSwh & 51 & 459 & 56 & 297 & 113 \\
\hline Husn & 35.89530 & 32.48956 & 680 & BSwk & 44 & 402 & 42 & 259 & 96 \\
\hline Khanasira & 36.06110 & 32.39829 & 860 & BSwk & 51 & 223 & 34 & 183 & 75 \\
\hline $\begin{array}{c}\text { Wadi EL } \\
\text { Yabis }\end{array}$ & 35.61996 & 32.38046 & -200 & BWwh & 41 & 326 & 44 & 209 & 73 \\
\hline Ibbin & 35.83042 & 32.36245 & 1105 & Csa & 44 & 590 & 71 & 370 & 149 \\
\hline Mafraq & 36.22202 & 32.35032 & 695 & BWwk & 44 & 163 & 23 & 104 & 44 \\
\hline Ajloun & 35.76329 & 32.33342 & 760 & Csa & 51 & 638 & 74 & 407 & 156 \\
\hline Um-Quttein & 36.62618 & 32.32299 & 986 & BWwk & 47 & 176 & 25 & 108 & 56 \\
\hline Kufrenja & 35.71463 & 32.29516 & 640 & BSwk & 41 & 617 & 74 & 404 & 145 \\
\hline Jarash & 35.91051 & 32.28005 & 585 & BSwk & 46 & 352 & 41 & 228 & 92 \\
\hline $\begin{array}{c}\text { Deir Alla } \\
\text { NRA }\end{array}$ & 35.63111 & 32.19021 & -180 & BWwh & 46 & 294 & 36 & 185 & 73 \\
\hline Safawi & 37.10541 & 32.19004 & 715 & BWwk & 47 & 68 & 13 & 45 & 20 \\
\hline Sukhna & 36.08509 & 32.12623 & 500 & BWwh & 46 & 182 & 24 & 113 & 45 \\
\hline Jubeiha & 35.86056 & 32.03704 & 980 & BSwk & 44 & 473 & 49 & 301 & 123 \\
\hline Salt & 35.74030 & 32.03228 & 796 & BSwk & 52 & 623 & 63 & 401 & 152 \\
\hline $\begin{array}{l}\text { Ministry of } \\
\text { Water }\end{array}$ & 35.94788 & 31.92874 & 680 & BSwk & 50 & 548 & 55 & 352 & 143 \\
\hline Sahab & 36.01989 & 31.86479 & 830 & BSwk & 53 & 492 & 25 & 175 & 73 \\
\hline $\mathrm{Na}$ 'ur & 35.84267 & 31.86290 & 800 & BSwk & 47 & 486 & 62 & 328 & 139 \\
\hline $\begin{array}{c}\text { EL- } \\
\text { Muwaggar }\end{array}$ & 36.10970 & 31.80881 & 910 & BWwk & 53 & 254 & 19 & 138 & 52 \\
\hline Madaba & 35.80697 & 31.70669 & 785 & BSwk & 53 & 333 & 39 & 221 & 92 \\
\hline Jiza & 35.96575 & 31.68886 & 705 & BWwk & 53 & 211 & 23 & 129 & 59 \\
\hline Wadi Wala & 35.77626 & 31.54667 & 350 & BWwh & 53 & 246 & 28 & 164 & 80 \\
\hline Rabba & 35.74983 & 31.25825 & 970 & BSwk & 53 & 337 & 35 & 214 & 88 \\
\hline Karak & 35.70852 & 31.17075 & 1000 & BSwk & 43 & 357 & 34 & 222 & 93 \\
\hline Mazar & 35.70766 & 31.05183 & 1140 & BSwk & 48 & 318 & 32 & 210 & 91 \\
\hline
\end{tabular}




\begin{tabular}{|c|c|c|c|c|c|c|c|c|c|}
\hline \multicolumn{10}{|l|}{ Continued } \\
\hline Ghores-Safi & 35.47846 & 31.02402 & -285 & BWwh & 50 & 40 & 9 & 43 & 15 \\
\hline Tafeile & 35.61365 & 30.82535 & 1000 & BSwk & 52 & 267 & 18 & 184 & 75 \\
\hline Busaira & 35.61639 & 30.73628 & 1100 & BSwk & 51 & 268 & 19 & 187 & 71 \\
\hline Wadi Mousa & 35.48456 & 30.31189 & 1100 & BWwk & 51 & 180 & 15 & 121 & 39 \\
\hline Ma'an & 35.74516 & 30.18851 & 1080 & BWwk & 47 & 42 & 6 & 24 & 15 \\
\hline Ras En-Naqb & 35.49465 & 29.99524 & 1570 & BWwk & 50 & 129 & 14 & 95 & 34 \\
\hline Aqaba & 35.00406 & 29.51438 & 40 & BWwh & 50 & 34 & 5 & 24 & 8 \\
\hline
\end{tabular}

and latitude $(\mathrm{N})$ control rainfall erosivity, and to explain the pattern of rainfall erosivity was examined. Correlation analysis between average annual precipitation $(\mathrm{mm})$, seasonal precipitation $(\mathrm{mm})$, altitude $(\mathrm{m})$, latitude and longitude against $R$-values were investigated to identify the degree of relationship between rainfall erosivity and annual precipitation, and between $R$-values and other site parameters. Such procedures are necessary to evaluate average annual precipitation and site parameters for the prediction of long-term annual erosivity over Jordan.

An Excel sheet of the annual and monthly precipitation $(\mathrm{mm})$ pertaining to the 40 rainfall stations, parallel with the coordinates of each station according to the Geography WGS 1984, was installed. Then rainfall erosivity was calculated based on the selected three regression equations. Afterwards, the Excel document was imported to the Arc GIS 10.3 software, along with the transformation of point data to spatial data based on their coordinates $(x, y)$ of each rainfall station. Using 3D Analyst available in the Arc tool box, a shape file was established and subjected to Raster interpretation (Spline method) to generate an areal Raster layer through the application of the spatial Analyst tool. Then a contour isoline layer (with contour interval of $10 \mathrm{~m}$ ) was executed and kept as a shape file. Through geoprocessing (Clip function), the contours which cover the entire area of Jordan were extracted, and finally the annual and seasonal rainfall erosivity maps were compiled.

\section{Results and Discussion}

\subsection{Spatial Distribution of Rainfall Erosivity}

The spatial distribution of estimated annual rainfall erosivity over Jordan is illustrated in Figures 3(a)-(d); Figures 4(a)-(d); and Figures 5(a)-(d). Overall, the spatial distribution of annual rainfall erosivity can be interpreted based on morphological (relief), annual rainfall distribution, and climatic zones according to Köppen (Figure 2). The estimated rainfall erosivity values range from 91 - 311 [32] [41] [42] MJ mm $\cdot \mathrm{ha}^{-1} \cdot \mathrm{h}^{-1} \cdot \mathrm{yr}^{-1}$. The average computed erosivity is 200.1, 15707, and $153.97 \mathrm{MJ} \mathrm{mmha}^{-1} \cdot \mathrm{h}^{-1} \cdot \mathrm{yr}^{-1}$ respectively. The standard deviation of annual rainfall erosivity values is $63.85,128.08$, and 60 for the three regression equations. The coefficient of variation for the estimated $R$-values is $31.9,81.2$ 


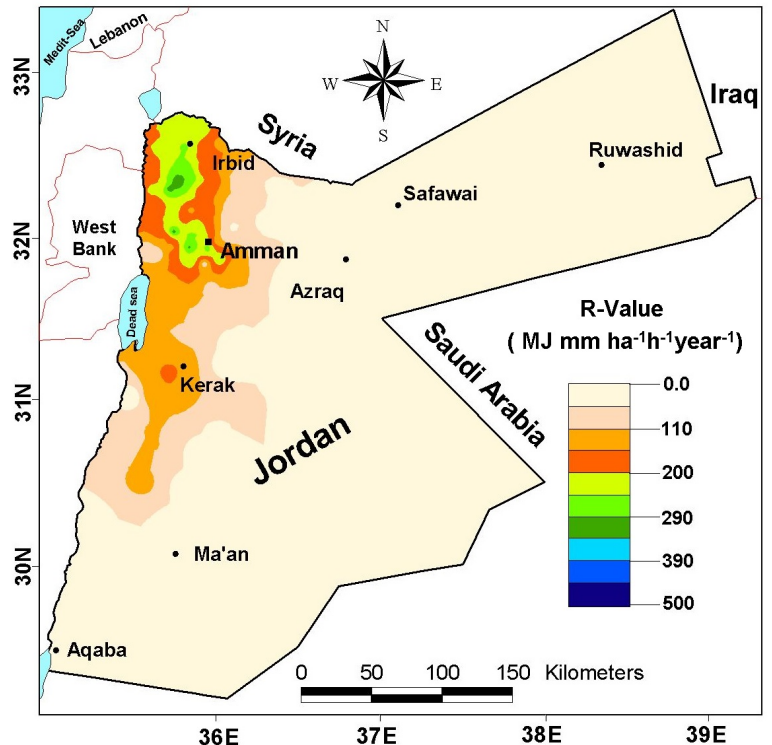

(a)

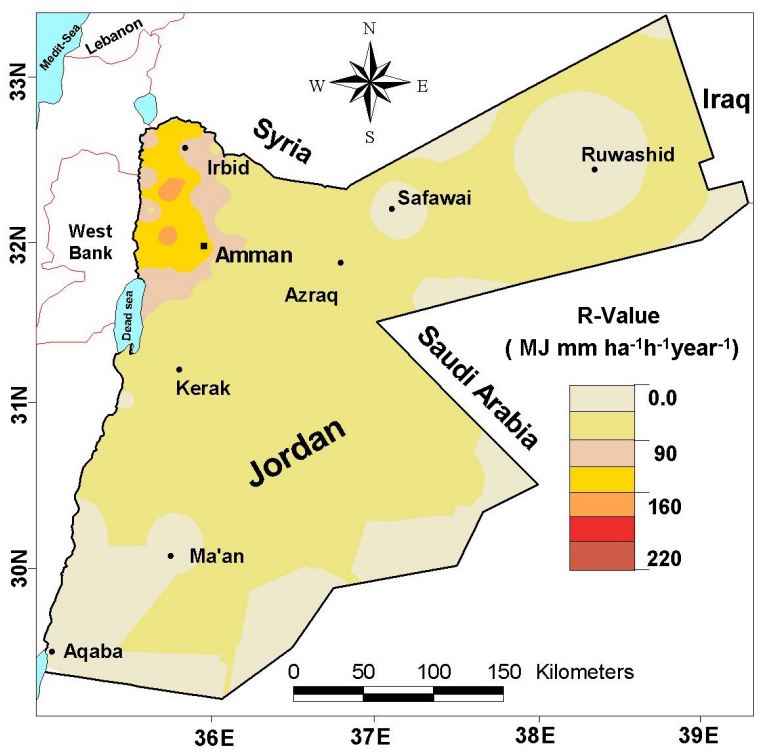

(c)

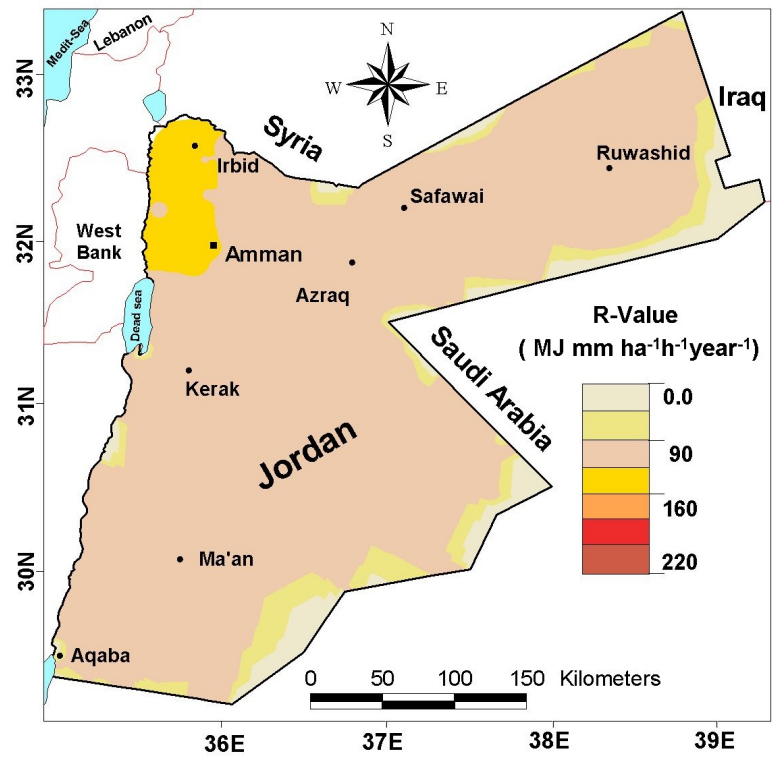

(b)

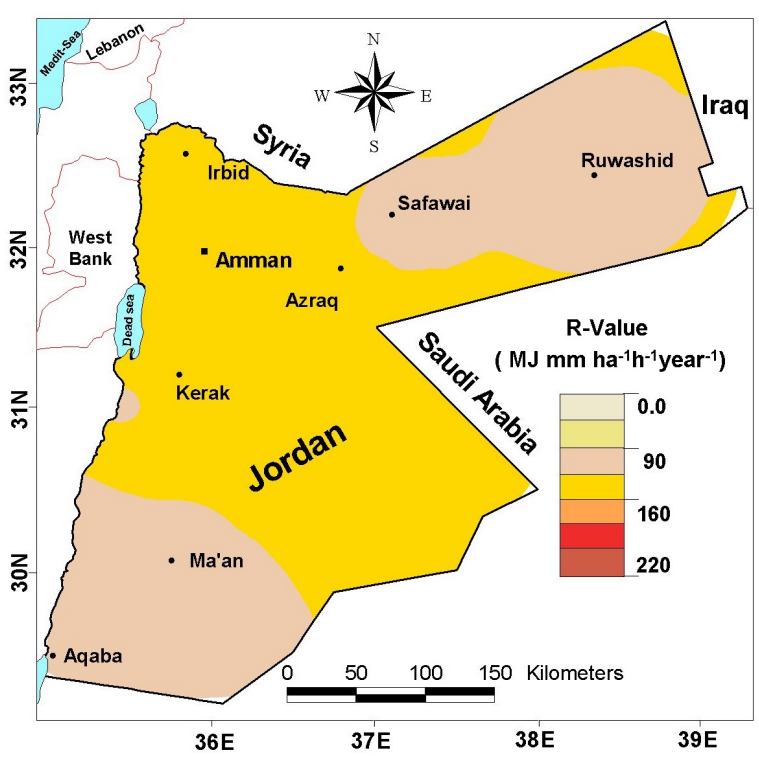

(d)

Figure 3. Spatial distribution of rainfall erosivity [32] model (a) Annual; (b) Autumn; (c) Winter; and (d) Spring.

and 39 respectively (Table 3). A remarkable variation is observed between the estimated rainfall erosivity values according to Eltaif et al. [42], while the least variation is observed in $R$-values computed in terms of Singh et al. [32]. The influence of climate on annual rainfall erosivity can be observed in Figure 2. As the country is dominated by an arid climate with low annual rainfall, the lower values are found in arid regions (BW), where the average annual rainfall is below $100 \mathrm{~mm}$. Aqaba, Ma'an, Safawi, and Rwaished (Figure 2, Table 1) are typical examples. The mean annual $R$-values for these weather stations (BW climate) are: $91,94,104$, and $106 \mathrm{MJ} \mathrm{mm} \cdot \mathrm{ha}^{-1} \cdot \mathrm{h}^{-1} \cdot \mathrm{yr}^{-1}$ according to the Singh et al. [32] 


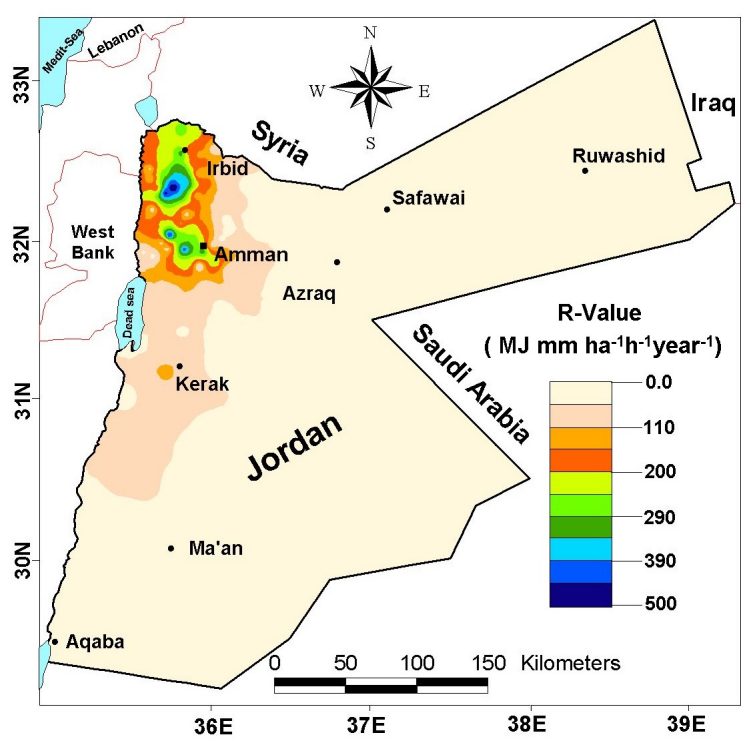

(a)

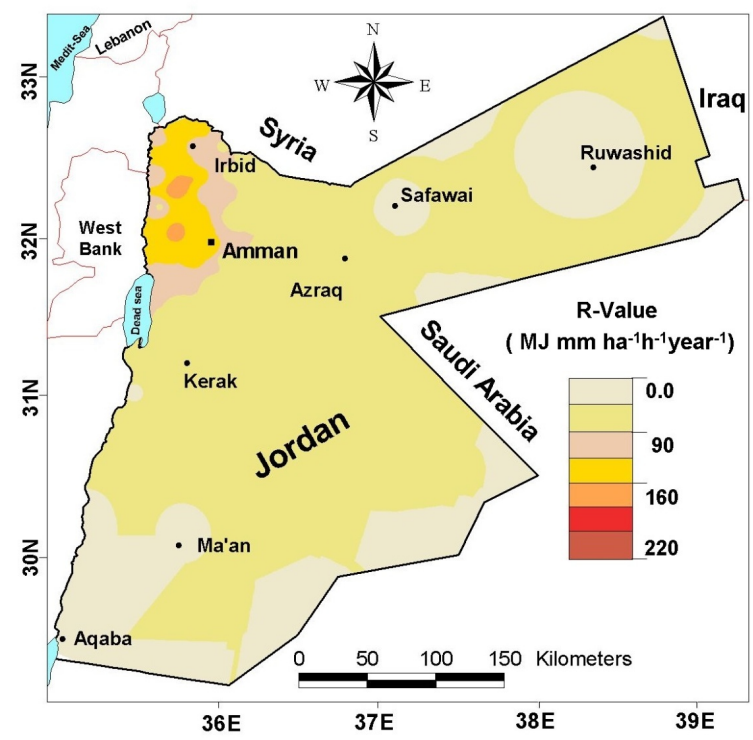

(c)

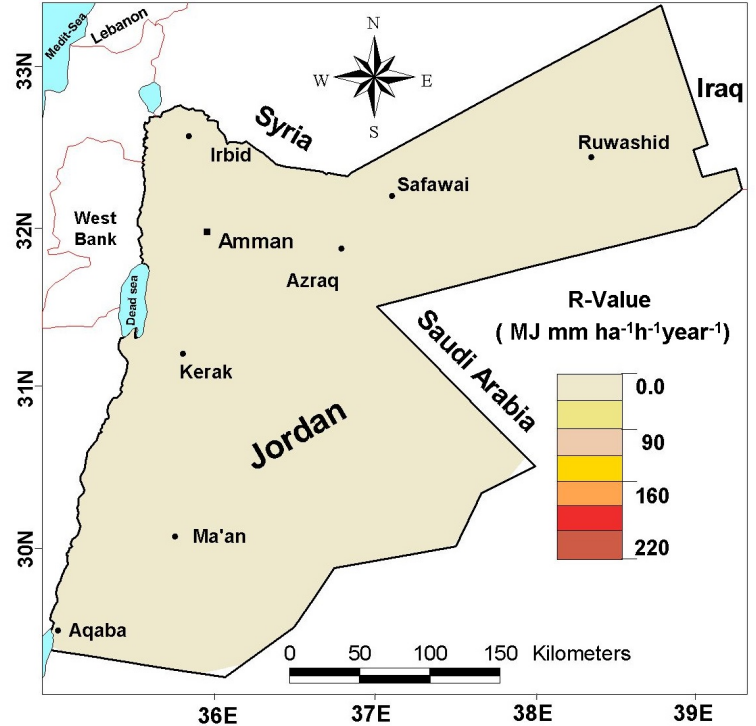

(b)

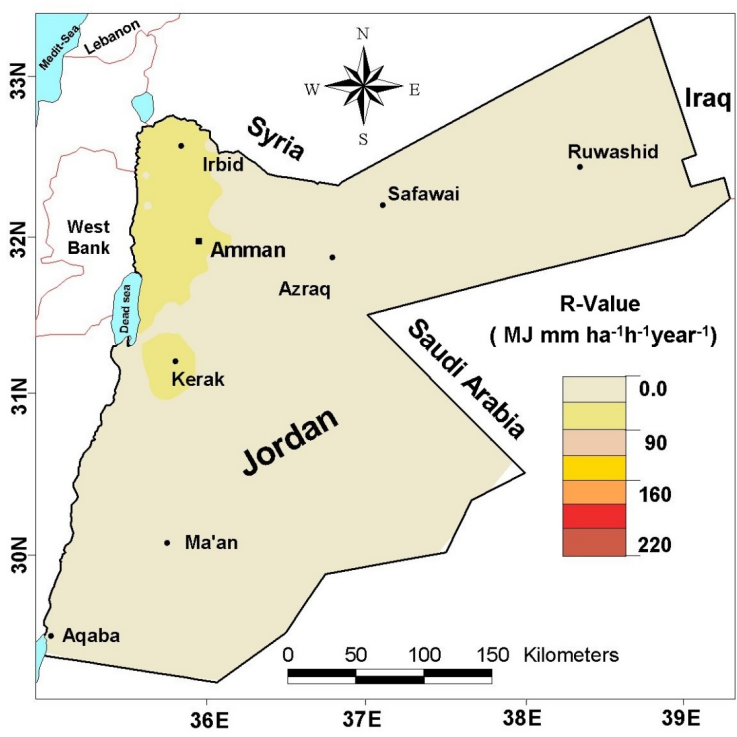

(d)

Figure 4. Spatial distribution of rainfall erosivity [42] model (a) Annual; (b) Autumn; (c) Winter; and (d) Spring.

equation, and $28,29,33$, and $34 \mathrm{MJ} \mathrm{mm} \cdot \mathrm{ha}^{-1} \mathrm{~h}^{-1} \cdot \mathrm{yr}^{-1}$ with reference to the Eltaif et al. [42] model. According to the El-Swaify et al. [41] equation, the $R$-values are: $50,53,62$, and $65 \mathrm{MJ} \mathrm{mm} \cdot \mathrm{ha}^{-1} \mathrm{~h}^{-1} \cdot \mathrm{yr}^{-1}$ respectively. Although the four weather stations are categorized under arid (BW) climate, the calculated annual rainfall erosivity is varied, and prominent differences are found among these values. Additionally, the differences of $R$-values computed based on the equation of Singh et al. [32] and Eltaif et al. [42] equations are greater compared with the differences of $R$-values derived based on the equation of Eltaif et al. [42] and El-Swaify et al. [41]. 


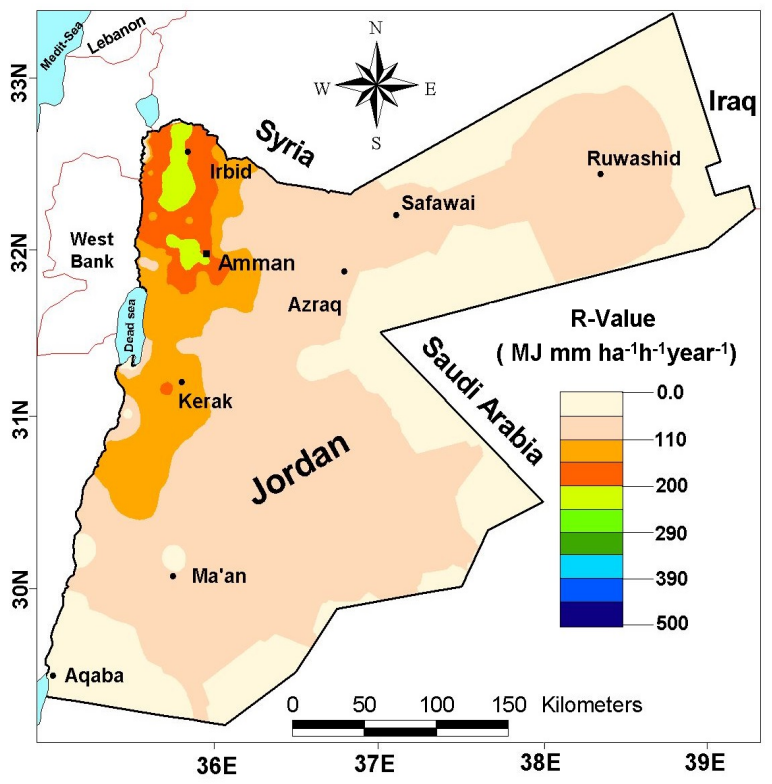

(a)

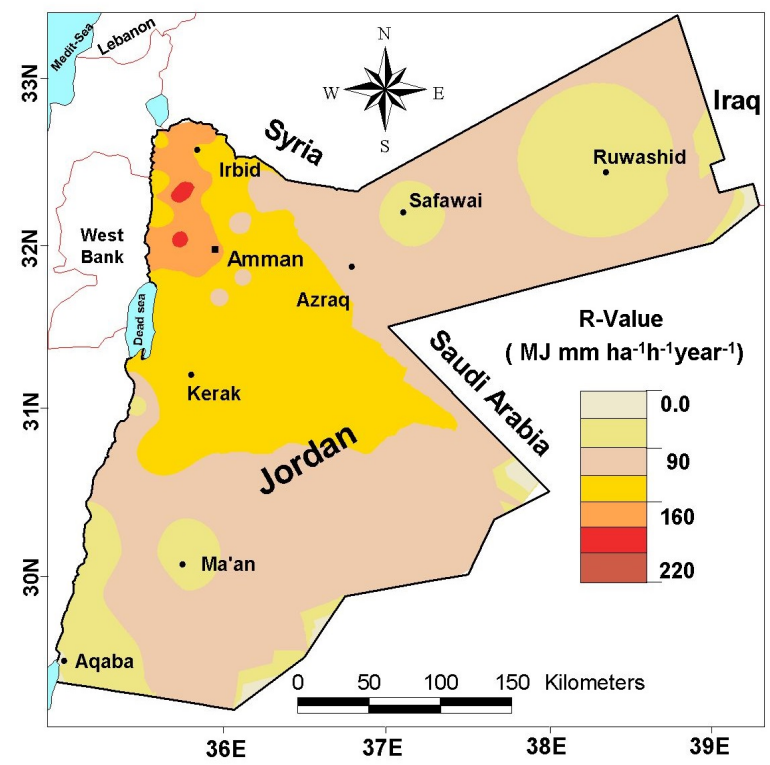

(c)

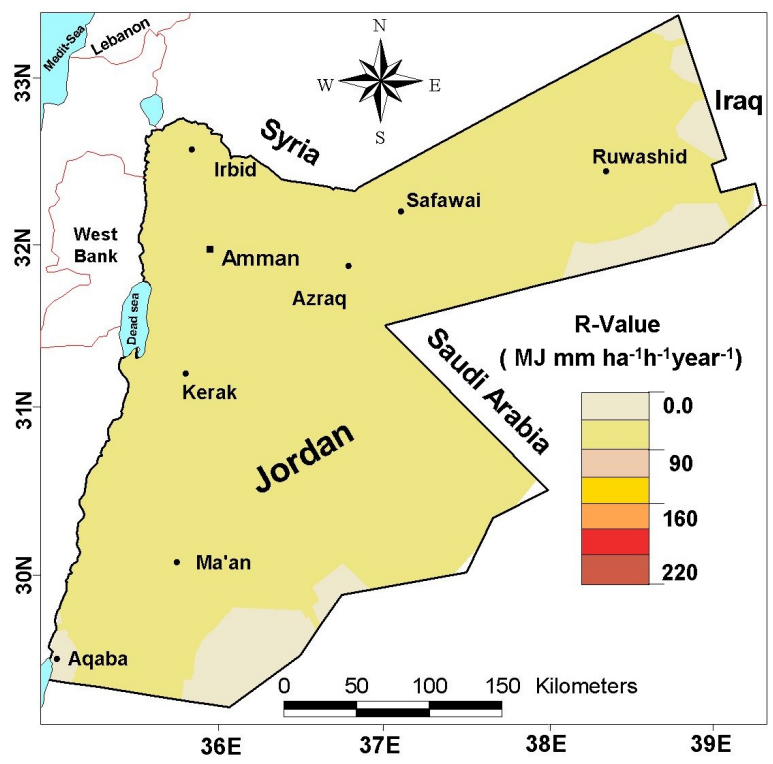

(b)

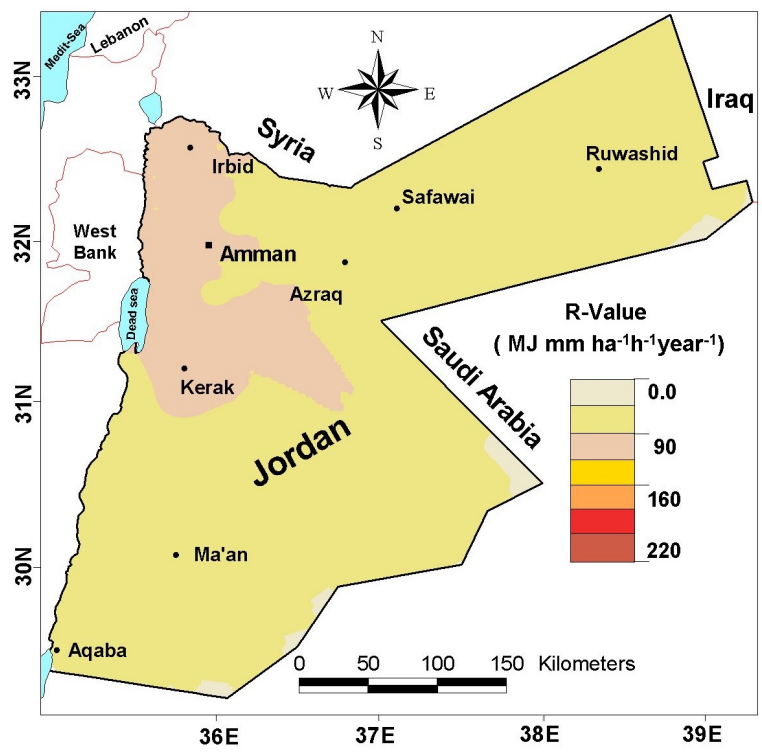

(d)

Figure 5. Spatial distribution of rainfall erosivity [41] model (a) Annual; (b) Autumn; (c) Winter; and (d) Spring.

The highest $R$-values are found in the northern highlands, while moderate annual erosivity values dominate a narrow strip of semi-arid climate (BS) where average annual rainfall is $150-250 \mathrm{~mm}$. Likewise, the lowest values are observed in the southern, eastern, and northern deserts of the country (Table 2, Figure 2). The highest annual rainfall erosivity values are found over the dry-Mediterranean climate (Csa) zone, with average annual rainfall ranging from 300 to $650 \mathrm{~mm}$. This zone is restricted to the northern highlands of Jordan and represented by the following rainfall stations: Kufr Saum, Deir Abi Said, Ajlune Kufranja and 
Table 2. $R$-values for the 40 rainfall stations used in the study.

\begin{tabular}{|c|c|c|c|c|c|c|c|c|c|c|c|c|}
\hline \multirow[b]{3}{*}{ Weather station } & \multicolumn{12}{|c|}{$R$-value $\left(\mathrm{MJ} \mathrm{mm} \cdot \mathrm{ha}^{-1} \cdot \mathrm{h}^{-1} \cdot\right.$ year $\left.^{-1}\right)$} \\
\hline & \multicolumn{4}{|c|}{ Singh et al. Model [32] } & \multicolumn{4}{|c|}{ Eltaif et al. Model [32] } & \multicolumn{4}{|c|}{ El-Swaify et al. Model [32] } \\
\hline & $\begin{array}{c}\text { Mean } \\
\text { annual }\end{array}$ & Autumn & Winter & Spring & $\begin{array}{c}\text { Mean } \\
\text { annual }\end{array}$ & Autumn & Winter & spring & Mean annual & Autumn & Winter & Spring \\
\hline Kufr Saum & 267 & 101 & 197 & 127 & 284 & 31 & 113 & 44 & 220 & 60 & 153 & 85 \\
\hline Kharja & 245 & 98 & 187 & 118 & 212 & 30 & 99 & 39 & 198 & 57 & 143 & 76 \\
\hline Um Qeis & 251 & 103 & 194 & 117 & 230 & 32 & 109 & 39 & 204 & 61 & 150 & 75 \\
\hline Baqura AGR & 221 & 100 & 168 & 111 & 153 & 31 & 77 & 36 & 175 & 58 & 124 & 69 \\
\hline Ramtha & 181 & 91 & 146 & 105 & 91 & 28 & 57 & 34 & 137 & 50 & 103 & 64 \\
\hline Irbid & 229 & 99 & 171 & 117 & 172 & 31 & 80 & 39 & 183 & 58 & 127 & 75 \\
\hline Rwaished & 106 & 84 & 92 & 89 & 34 & 25 & 28 & 27 & 65 & 43 & 51 & 48 \\
\hline Gumaim & 246 & 103 & 201 & 124 & 215 & 32 & 118 & 43 & 200 & 61 & 156 & 82 \\
\hline Deir Abi Said & 299 & 99 & 187 & 120 & 214 & 31 & 98 & 41 & 199 & 58 & 142 & 78 \\
\hline Husn & 225 & 94 & 173 & 114 & 163 & 29 & 82 & 37 & 179 & 53 & 129 & 72 \\
\hline Khanasira & 160 & 91 & 145 & 106 & 69 & 28 & 57 & 34 & 117 & 50 & 103 & 65 \\
\hline Wadi EL Yabis & 197 & 95 & 155 & 105 & 113 & 29 & 64 & 34 & 153 & 54 & 112 & 64 \\
\hline Ibbin & 293 & 105 & 213 & 133 & 401 & 33 & 139 & 48 & 245 & 63 & 168 & 91 \\
\hline Mafraq & 138 & 87 & 117 & 95 & 52 & 26 & 39 & 29 & 96 & 47 & 75 & 54 \\
\hline Ajloun & 311 & 106 & 227 & 136 & 505 & 34 & 167 & 50 & 262 & 64 & 181 & 93 \\
\hline Um-Quttein & 143 & 88 & 118 & 99 & 55 & 27 & 40 & 31 & 100 & 47 & 76 & 58 \\
\hline Kufrenja & 303 & 106 & 226 & 132 & 456 & 34 & 164 & 47 & 254 & 64 & 180 & 89 \\
\hline Jarash & 207 & 94 & 162 & 112 & 128 & 29 & 71 & 37 & 162 & 53 & 118 & 71 \\
\hline Deir Alla NRA & 186 & 92 & 146 & 105 & 97 & 28 & 57 & 34 & 141 & 51 & 103 & 64 \\
\hline Safawi & 104 & 84 & 95 & 86 & 33 & 25 & 29 & 26 & 62 & 43 & 54 & 46 \\
\hline Sukhna & 145 & 88 & 120 & 95 & 57 & 26 & 41 & 29 & 102 & 47 & 78 & 54 \\
\hline Jubeiha & 251 & 97 & 188 & 124 & 229 & 30 & 100 & 43 & 204 & 56 & 144 & 82 \\
\hline Salt & 305 & 102 & 225 & 134 & 470 & 32 & 162 & 49 & 257 & 61 & 179 & 92 \\
\hline $\begin{array}{l}\text { Ministry of } \\
\text { Water }\end{array}$ & 278 & 99 & 207 & 131 & 328 & 31 & 128 & 47 & 230 & 58 & 162 & 89 \\
\hline Sahab & 258 & 88 & 143 & 105 & 250 & 27 & 55 & 34 & 211 & 47 & 100 & 64 \\
\hline $\mathrm{Na}$ ur & 255 & 102 & 198 & 129 & 243 & 32 & 114 & 46 & 209 & 60 & 153 & 87 \\
\hline EL -Muwaggar & 171 & 86 & 129 & 98 & 80 & 26 & 46 & 30 & 127 & 45 & 87 & 57 \\
\hline Madaba & 200 & 93 & 159 & 112 & 117 & 28 & 68 & 37 & 155 & 52 & 116 & 71 \\
\hline Jiza & 156 & 87 & 126 & 100 & 65 & 26 & 44 & 31 & 112 & 47 & 84 & 59 \\
\hline Wadi Wala & 168 & 89 & 139 & 108 & 77 & 27 & 52 & 35 & 125 & 48 & 96 & 67 \\
\hline Rabba & 201 & 92 & 157 & 111 & 119 & 28 & 66 & 36 & 156 & 51 & 113 & 69 \\
\hline Karak & 209 & 91 & 160 & 113 & 131 & 28 & 69 & 37 & 163 & 50 & 116 & 71 \\
\hline Mazar & 194 & 91 & 155 & 112 & 109 & 28 & 65 & 37 & 150 & 50 & 112 & 70 \\
\hline
\end{tabular}




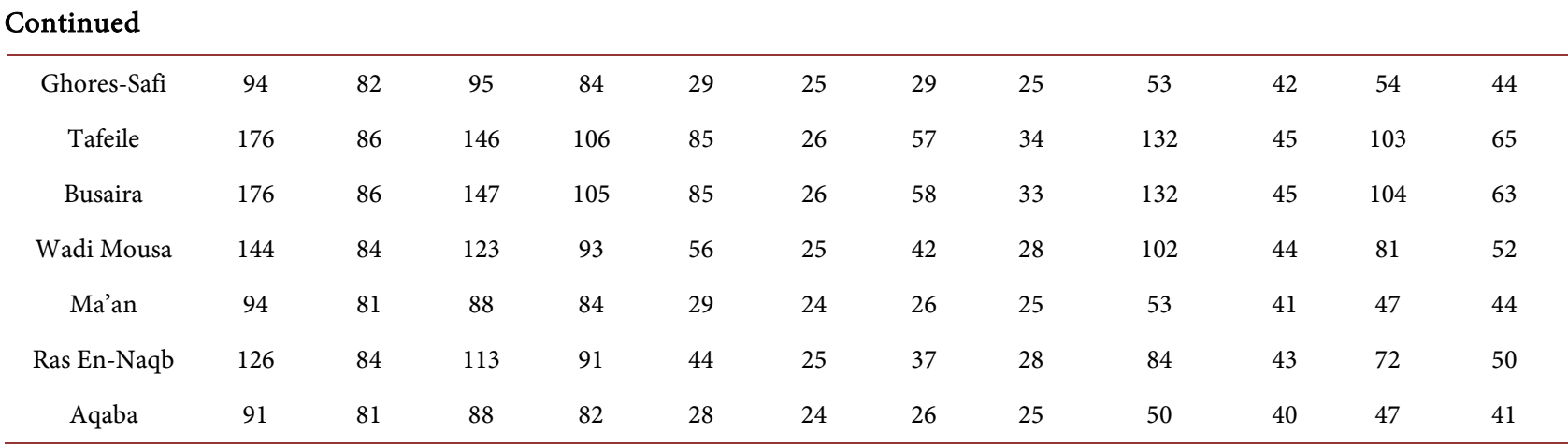

Salt which are classified as Csa "dry Mediterranean" climate, where the highest annual rainfall in the country (mean annual rainfall ranges from $325 \mathrm{~mm}$ to 638 $\mathrm{mm}$ ) occurs. Thus, the highest annual rainfall erosivity is attained over the northern highlands. The annual $R$-values according to the Singh et al. [32] equation vary from 267 to $305 \mathrm{MJ} \mathrm{mm} \cdot \mathrm{ha}^{-1} \cdot \mathrm{h}^{-1} \cdot \mathrm{yr}^{-1}$ (Table 2). In contrast, the annual $R$-values vary from 204 to 505 according to the equation of Eltaif et al. [42]. Higher erosivity values here are highly inconsistent with the Eltaif et al. [42] model. This is not unexpected since the model has been elaborated and tested specifically on the northwestern highlands of Jordan including the weather stations mentioned above. Furthermore, the annual rainfall erosivity decreases noticeably with reference to the equation of El-Swaify et al. [41], ranging from 199 to $262 \mathrm{MJ} \mathrm{mm} \cdot \mathrm{ha}^{-1} \cdot \mathrm{h}^{-1} \cdot \mathrm{yr}^{-1}$. High annual rainfall erosivity values over the northern highland are not only in accordance with $R$-values estimated using the Eltaif et al. [42] equation, but are also inconsistent with the results reported by Farhan et al. [20], and Farhan and Nawaiseh [21] regarding soil loss prediction using the RUSLE approach in the highlands (Wadi Kufranja and Wadi Kerak watersheds respectively). Noticeable differences are affirmed between the annual $R$-value produced by the three equations. However, high erosivity values occur in Ajlune, Kufranja, Irbid, and Salt areas (northern Jordan); they are caused by a relatively high amount of precipitation, intensity and kinetic energy of rain, and also due to the predominance of high slope categories. A pronounced gradient in the annual rainfall erosivity is recognized to the east and south of the northern highlands, i.e., towards the eastern and southern desert. Analysis of winter rainfall erosivity confirms this observation, where the pattern of winter rainfall erosivity resembles the patterns of annual rainfall erosivity generated based on the three regression equations. Some $70 \%$ of the total precipitation occurs in winter (December-February), where the average winter rainfall varies from $209 \mathrm{~mm}$ to 407 $\mathrm{mm}$ in the Csa climate zone. Severe rainstorms are common, and associated with a maximum daily intensity of $2.1-6.6 \mathrm{~mm} \cdot \mathrm{hr}^{-1}$ [6] [8]. Severe soil erosion is therefore predictable. Also, two peaks of rainfall erosivity are observed in winter and spring (March-April). The three maps (Figure 3(c), Figure 4(c) and Figure 5 (c)) clearly reveal that the spatial distribution of rainfall erosivity in winter season resembles the pattern of spatial distribution of annual rainfall erosivity, 
but with lower values. By contrast, the autumn rainfall erosivity (September-October) is at a minimum. The average autumn rainfall varies from 41 to 74 $\mathrm{mm}$ over the northern highlands (Csa climate class), and ranges from 5 to 36 $\mathrm{mm}$ over the arid and semi-arid zones. With respect to the Eltaif et al. [42] equation, $R$-values for the 40 weather stations (or sites)range in autumn from 24 to $34\left(\mathrm{MJ} \mathrm{mm} \cdot \mathrm{ha}^{-1} \cdot \mathrm{h}^{-1} \cdot \mathrm{yr}^{-1}\right.$ ), Whereas, the computed $R$-vales based on Singh et al. [32] yielded higher values and varied from 81 to 106 (MJ mm.ha ${ }^{-1} \cdot \mathrm{h}^{-1} \cdot \mathrm{yr}^{-1}$ ) (Table 2). Over the northern highlands, $R$-values calculated with reference to El-Swaify et al. [41] were close to moderate erosivity values ranging from 40 to $64\left(\mathrm{MJ} \mathrm{mm} \cdot \mathrm{ha}^{-1} \cdot \mathrm{h}^{-1} \cdot \mathrm{yr}^{-1}\right)$. It is obvious that the Singh et al. [32] model overestimates autumn rainfall erosivity, whereas Eltief et al. [42] underestimates autumn rainfall erosivity. The higher $R$-values obtained for the BS and BW climatic zones through utilizing the equations of Singh et al. [32] and El-Swaify et al. [41] vary from $81-<100$ and $40-<50 \mathrm{MJ} \mathrm{mm} \cdot \mathrm{ha}^{-1} \cdot \mathrm{h}^{-1} \cdot \mathrm{yr}^{-1}$ respectively. In this regard, the spatial distribution of rainfall erosivity in autumn is determined by the spotty character of the rainfall [70] and convective thunder storms with some effect of orography (Schick [10] [71]). These types of rainfall are pronounced in autumn (October-November) and spring (March-May) thunderstorms and are influenced by the effect of the Red Sea trough [72]. In the eastern and southern desert of Jordan, heavy rainstorms normally occur at an annual average of four events [73]. By examining the spatial distribution of spring rainfall erosivity, two patterns can be identified regardless of the variation presents among $R$-values derived based on the three models (Table 2). However, the equations of El-Swaify et al. [41], and Eltaif et al. [42] showed the northern and central highlands as distinctive patterns, where the average spring rainfall range from $73 \mathrm{~mm}$ to $156 \mathrm{~mm}$. In the recent past, Farhan [8] stated that rainfall seasonality and intensity were important factors not only in the occurrence of landslides, but also in maximizing rainfall erosivity in winter and spring [21] over the central and northern highlands of Jordan. Landslides as recorded (1956-1993) indicate that shallow and deep-seated landslides are disrupted, or reactivated whenever the maximum rainfall in 24 hours approaches or exceeds $100 \mathrm{~mm}$, and the total monthly rainfall exceeds $200 \mathrm{~mm}$. Such conditions are repetitive phenomena in winter and spring. Another noteworthy result is that the estimated rainfall erosivity using the equation of Singh et al. [32] shows that the southern and northeastern desert appear as a perceptible pattern emerging in the rainfall erosivity map of spring (the average spring rainfall varies from $8 \mathrm{~mm}$ to only $80 \mathrm{~mm}$ ). Here, the impact of exceptionally heavy rainstorms, and the spotty and convective thunderstorms of spring explain the presence of such a rainfall erosivity pattern.

\subsection{Relationship between Annual Precipitation and Rainfall Erosivity}

The relationship between annual precipitation and annual rainfall erosivity for the 40 weather stations was examined. Table 3 exhibits the mean, minimum, 
maximum, and $\mathrm{CV}$ of average annual precipitation and annual rainfall erosivity. The mean annual rainfall for all the stations is $329.92 \mathrm{~mm}$; the minimum annual rainfall is $37 \mathrm{~mm}$ recorded at Aqaba; while the maximum annual rainfall is 638 $\mathrm{mm}$, recorded at Ajlune. The mean annual rainfall erosivity for all stations was 200.1 (based on [32]), 157.7 (based on [42]), 153.97 (based on [41]) MJ mm MJ $\mathrm{mm} \cdot \mathrm{ha}^{-1} \cdot \mathrm{h}^{-1} \cdot \mathrm{yr}^{-1}$. The minimum rainfall erosivity achieved is $28 \mathrm{MJ}$ $\mathrm{mm} \cdot \mathrm{ha}^{-1} \cdot \mathrm{h}^{-1} \cdot \mathrm{yr}^{-1}$, and a maximum rainfall erosivity of $505 \mathrm{MJ} \mathrm{mm} \cdot \mathrm{ha}^{-1} \cdot \mathrm{h}^{-1} \cdot \mathrm{yr}^{-1}$ was estimated for Ajlune station (based on [42]). The CV of annual precipitation is 51.9 for all the stations, whereas the CV of annual rainfall erosivity is 31.9 (based on [32]), 81.2 (based on [42]), and 39 (based on [41]).

Regression analysis between $R$-values and annual precipitation ( $\mathrm{mm}$ ) with respect to three regression equation, reveals that the relationship between $R$-values and annual rainfall ( $\mathrm{mm}$ ) are positive and strong (Figure 6). $R^{2}$ value is 0.98 for $R$-values estimated according to Singh et al. [32], and $R^{2}=1$ for $R$-values achieved based on Eltaif et al. [42] and El-Swaify et al. [41]. Such a strong relationship has been verified by other researchers [36] [38] [39]. Table 4 illustrates Pearson's correlation matrix of annual/seasonal rainfall erosivity with reference to the three regression equations and other site parameters. The correlation between mean annual precipitation $(\mathrm{mm})$ and annual erosivity exhibits a very

Table 3. Descriptive statistics of annual and seasonal rainfall $(\mathrm{mm})$, and annual erosivity $\left(\mathrm{MJ} \mathrm{mm} \cdot \mathrm{ha}^{-1} \cdot \mathrm{h}^{-1} \cdot \mathrm{yr}^{-1}\right)$.

\begin{tabular}{|c|c|c|c|c|c|c|c|}
\hline \multicolumn{2}{|c|}{$R$-value and Rainfall } & Rainfall (mm) & Minimum & Maximum & Mean & Std. Deviation & $\begin{array}{c}\text { Coefficient of } \\
\text { Variation (CV \%) }\end{array}$ \\
\hline \multirow{4}{*}{\multicolumn{2}{|c|}{ Rainfall (mm) }} & $\begin{array}{l}\text { Mean Annual } \\
\text { Rainfall (mm) }\end{array}$ & 34 & 638 & 329.92 & 171.49 & 51.9 \\
\hline & & Autumn & 5 & 74 & 37.72 & 20.27 & 53.7 \\
\hline & & Winter & 24 & 407 & 211.07 & 109.53 & 51.9 \\
\hline & & Spring & 8 & 156 & 83.52 & 41.08 & 49.2 \\
\hline \multirow{12}{*}{$\begin{array}{c}R \text {-value } \\
\left(\mathrm{MJ} \mathrm{mm} \cdot \mathrm{ha}^{-1} \cdot \mathrm{h}^{-1} \cdot \text { year }^{-1}\right)\end{array}$} & \multirow{4}{*}{$\begin{array}{l}\text { Singh et al. } \\
\text { Model }\end{array}$} & $\begin{array}{l}\text { Mean Annual Rain } \\
\text { Erosivity }\end{array}$ & 91 & 311 & 200.10 & 63.85 & 31.9 \\
\hline & & Autumn & 81 & 106 & 92.72 & 7.45 & 8.0 \\
\hline & & Winter & 88 & 227 & 155.65 & 39.77 & 25.6 \\
\hline & & Spring & 82 & 136 & 109.20 & 15.02 & 13.8 \\
\hline & \multirow{4}{*}{$\begin{array}{l}\text { Eltaif } \text { et al. } \\
\quad \text { Model }\end{array}$} & $\begin{array}{c}\text { Mean Annual Rain } \\
\text { Erosivity }\end{array}$ & 28 & 505 & 157.70 & 128.08 & 81.2 \\
\hline & & Autumn & 24 & 34 & 28.42 & 2.83 & 10.0 \\
\hline & & Winter & 26 & 167 & 74.32 & 39.48 & 53.1 \\
\hline & & Spring & 25 & 50 & 35.95 & 7.08 & 19.7 \\
\hline & \multirow{4}{*}{$\begin{array}{l}\text { El-swaify et al. } \\
\text { [41] Model }\end{array}$} & $\begin{array}{l}\text { Mean Annual Rain } \\
\text { Erosivity }\end{array}$ & 50 & 262 & 153.97 & 60.00 & 39.0 \\
\hline & & Autumn & 40 & 64 & 51.67 & 7.06 & 13.7 \\
\hline & & Winter & 47 & 181 & 112.40 & 38.34 & 34.1 \\
\hline & & Spring & 41 & 93 & 67.75 & 14.41 & 21.3 \\
\hline
\end{tabular}




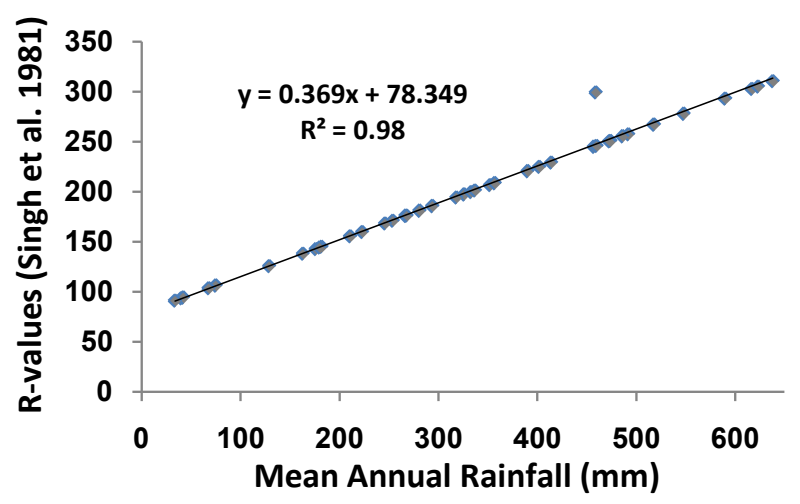

(a)

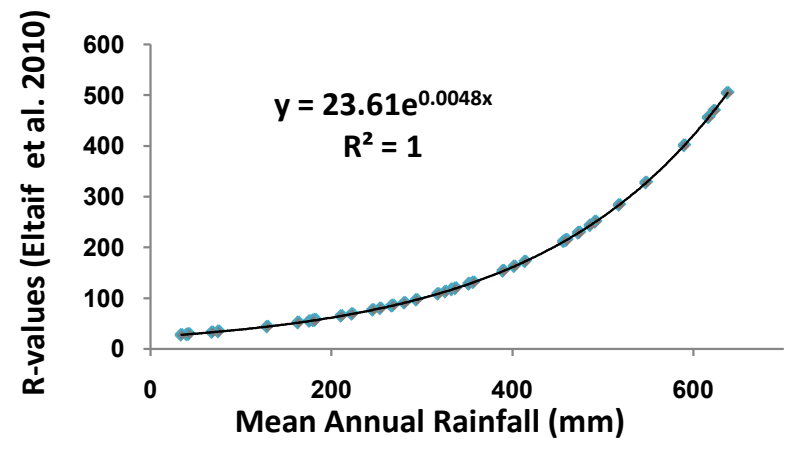

(b)

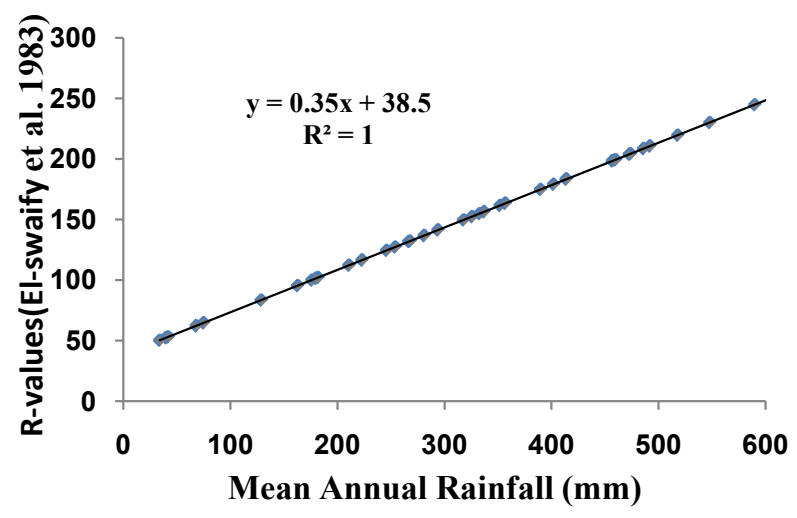

(c)

Figure 6. Scatter plot of annual $R$-Values vs. annual rainfall erosivity according to Singh et al. [32], Eltaif et al. [42], and El-Swaify et al. [41] models.

strong relationship. Calculated correlations are: 0.991, 0.922, and 1.00 based on the equation of Singh et al. [32]; Eltaif et al. [42]; and El-Swaify et al. [41] respectively (Table 4). Regression analysis was also conducted to evaluate the relationship between $R$-values and elevation $(\mathrm{m})$ with reference to the three models employed. It was found that the relationship between $R$-values and elevation $(\mathrm{m})$ is negligible (Figure 7), which means that no relationship exists between the two parameters ( $R^{2}$ values $=0.0001 ; 0.006$; and 0.001 respectively). In contrast, the correlation between annual erosivity and seasonal precipitation is very strong for all three regression equations. Correlation values are: $0.921,0.973$, and 0.964 


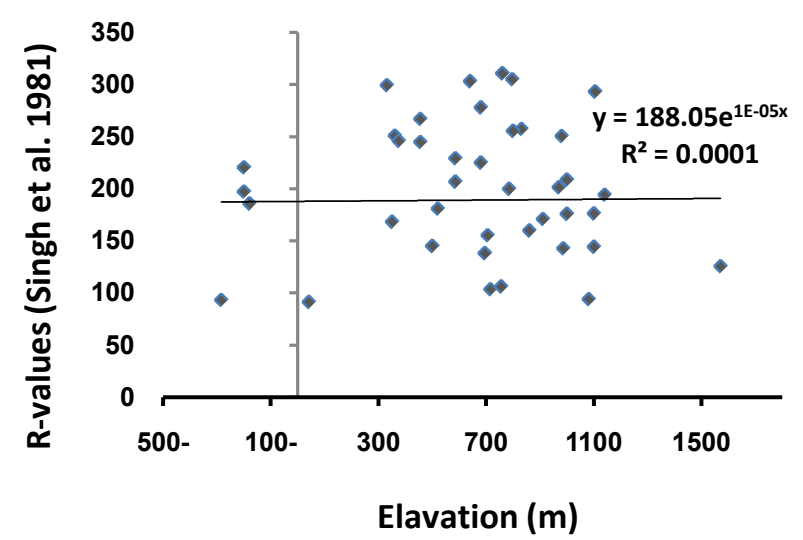

(a)

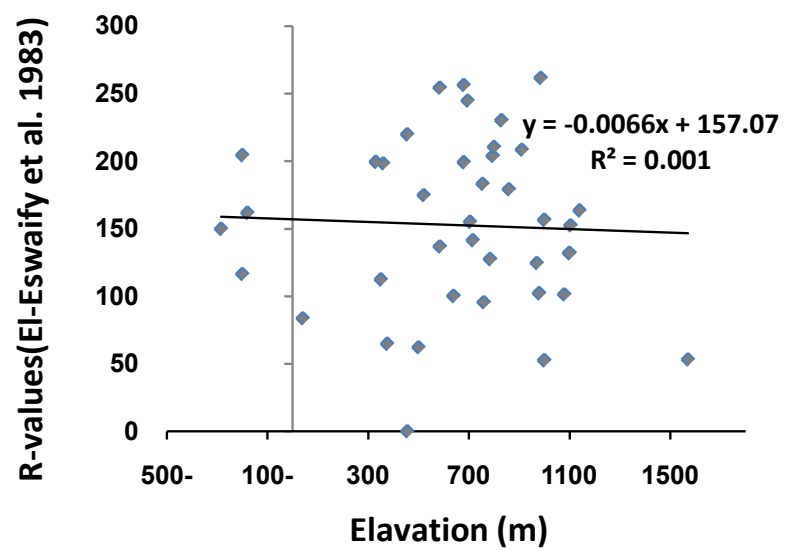

(b)

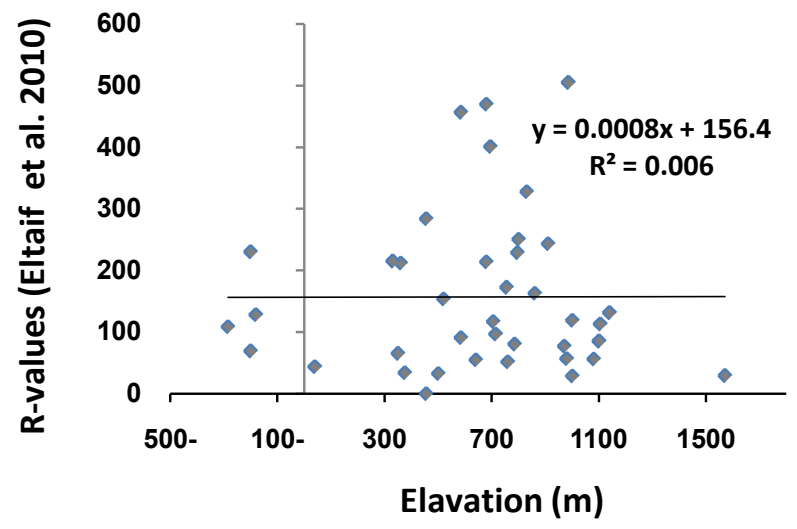

(c)

Figure 7. Scatter plot of annual $R$-Values vs. Elevation(m), according to Singh et al. [32], Eltaif et al. [42], and El-Swaify et al. [41] models.

respectively (Table 4). All correlations are significant at 0.01 level (2-tailed test). Moreover, moderate positive correlations exist between latitude $(\mathrm{N})$ and the mean annual/seasonal rainfall, and annual/seasonal erosivity. Correlation values vary from 0.407 to 0.642 , and all correlations are significant at 0.01 level (2-tailed test). Moreover, the correlation between elevation $(\mathrm{m})$ and annual rainfall erosivity is negative and weak with respect to the three regression equations 


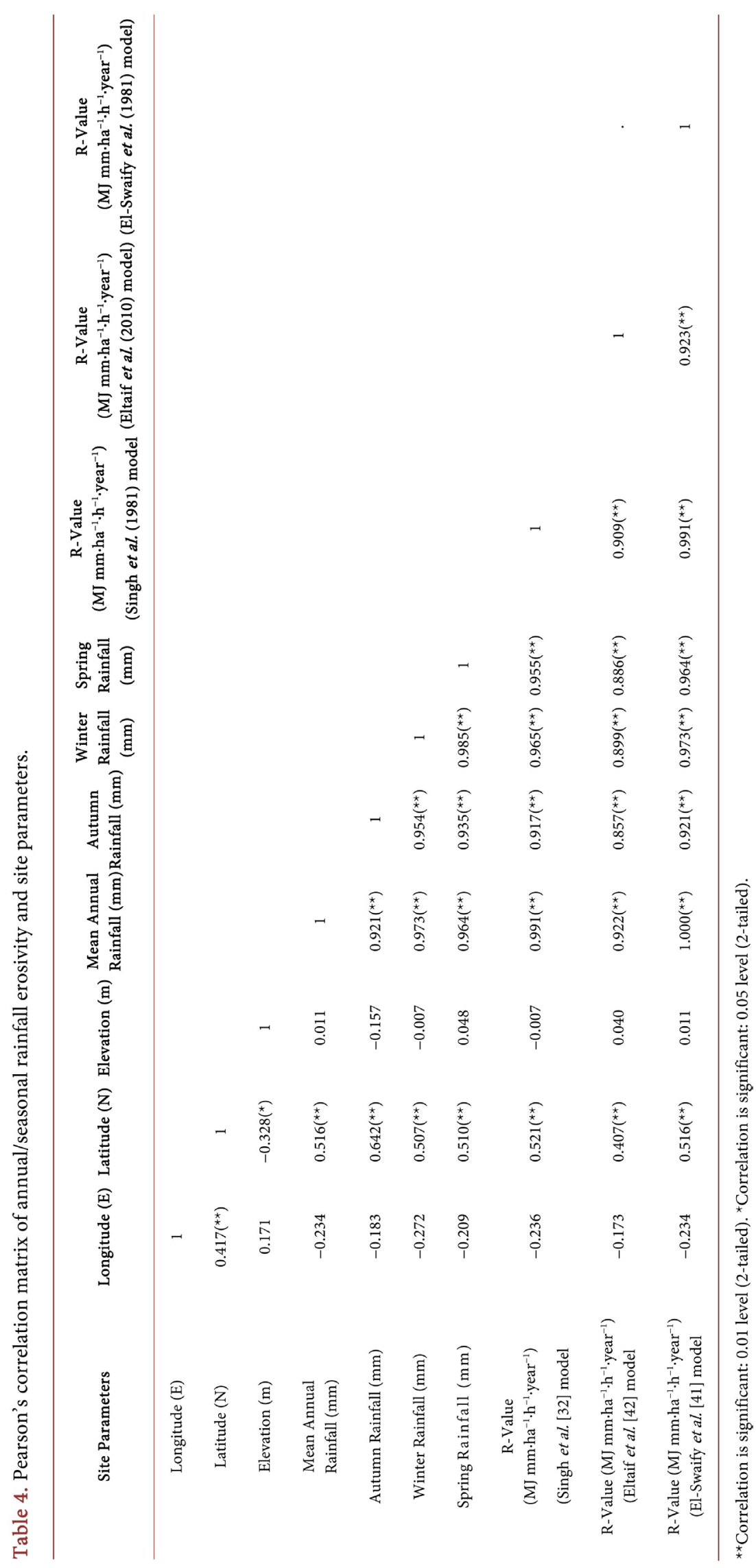


(Table 4), where correlation values range from -0.011 to -0.157 . Similarly, the correlation between longitude (E), and annual/seasonal rainfall and erosivity with reference to the three regression equations is very weak and negative as well. Generally, erosivity in Jordan decreases from the western highlands to the east towards the semi-arid and arid zones. In parallel, a sharp gradient is observed where erosivity decreases west of the high lands towards the Rift. Thus, no significant correlation is found between longitude $(\mathrm{E})$ and annual erosivity $(R$ values vary from -0.173 to -0.236 ) (Table 4 ). To conclude, the annual precipitation $(\mathrm{mm})$, and latitude parameters have a significant control over rainfall erosivity, whereas, other parameters (i.e., longitude and elevation (m)) show a weak, and/or negative correlation with respect to rainfall erosivity over Jordan.

\section{Conclusion}

Rainfall erosivity is a major parameter for USLE and RUSLE models, environmental processes, and climate change modeling. Simple linear regression models were developed and adopted in several countries to predict rainfall erosivity based on available annual precipitation data. In the present study, one regression equation (proposed particularly for northern Jordan) and two other models developed abroad (India, tropical and subtropical countries) were employed to estimate annual and seasonal rainfall erosivity in Jordan, based on available annual and seasonal precipitation. The database comprises 40 weather stations which provide reasonable spatial and temporal coverage of the country. The length of the rainfall record ranges from 41 to 53 continuous years. Annual and seasonal rainfall erosivity is strongly correlated with annual and seasonal precipitation rather than other parameters. $R^{2}$ varies from 0.838 to 0.999 for the three regression models. Likewise, the latitude parameter had a lower relationship with the annual and seasonal rainfall erosivity, but all correlations are significant at 0.01 level (2-tailed test). By contrast, the correlation observed between elevation (m) and annual/seasonal rainfall, and annual/seasonal erosivity is negative and weak ( $R$ varies from -0.11 to -0.157 ), whereas the correlation between annual precipitation and annual erosivity over the northern highlands of Jordan is positive and strong ( $R^{2}$ ranges from 0.838 to 0.999 for the three regression equations). No significant correlation was demonstrated between longitude (E) and annual erosivity. The present investigation confirms that two parameters can be useful to estimate erosivity over Jordan. The first parameter is the annual and seasonal precipitation, while the second parameter is latitude. Alternatively, elevation (m) accounts negligibly as rainfall erosivity. In the present study, the influence of land slope on rainfall erosivity has not been examined. Nevertheless, recent studies reported that in Wadi Kerak, $88 \%$ of soil erosion by area occurred on three slope categories $\left(0^{\circ}-6^{\circ}, 6^{\circ}-15^{\circ}\right.$ and $\left.15^{\circ}-25^{\circ}\right)$, and $11 \%$ of soil loss area dominated slopes $>25^{\circ}$ of inclination. About $6 \%$ slope areas $\left(15^{\circ}-25^{\circ}\right)$ suffer from extreme erosion. Areas of slope categories $0^{\circ}-6^{\circ}, 6^{\circ}-15^{\circ}$ and $15^{\circ}-25^{\circ}$ are affected by moderate to high soil erosion rates (Farhan and Nawaishe 2015). Simi- 
lar results were achieved for Wadi Kufranja in northern Jordan (Farhan et al. 2014). Thus, land with slopes ranging from $6^{\circ}$ to $25^{\circ}$ are the major contributor to soil loss in the highlands of Jordan, where the mean annual rainfall is $>250$ $\mathrm{mm}$. Accordingly, annual precipitation is still the most valid parameter to predict long-term annual rainfall erosivity for the entire country. To conclude, the simple regression equation which was proposed recently to estimate rainfall erosivity in northern Jordan, is proved to be trustworthy. All three regression equations employed were found effective in illustrating spatial changes of annual/seasonal rainfall erosivity with reference to corresponding variation in annual/seasonal precipitation. Regionally, the spatial variations in erosivity values afford substantial information/maps for predicting erosion in Jordan.

\section{References}

[1] Christopherson, G. and Guertin, D. (1995) Soil Erosion, Agricultural Intensification, and Iron Age Settlement in the Region of Tall El-Umeiri. Unpublished Paper Presented to the Annual Meeting of the American School of Oriental Research, Philadelphia.

[2] Cordova, G.E. (2000) Geomorphological Evidence of Intense Prehistoric Soil Erosion in the Highlands of Central Jordan. Physical Geography, 21, 538-567.

[3] Natural Resources Authority (1965) Soil Erosion in the East Ghor Region. Amman.

[4] McDonald Partners and Hunting Technical Services LTD (1965) East Bank Water Resources Summary Report. Central Water Authority, Amman.

[5] FAO, UNEP and UNESCO (1979) A Provisional Methodology of Soil Degradation Assessment. Rome.

[6] Farhan, Y. (1986) Landslides in Central Jordan with Special Reference to the March 1983 Rainstorm. Singapore Journal of Tropical Geography, 7, 80-97 https://doi.org/10.1111/j.1467-9493.1986.tb00174.x

[7] Farhan, Y. (1999) Landslide Hazards and Highway Engineering in Central and Northern Jordan. In: Griffiths, J.S., Stokes, M.R. and Thomas, R.G., Eds., Landslides, Balkema/Rotterdam/Brookfield, Rotterdam, 37-46.

[8] Farhan, Y. (2002) Slope Stability Problems in Central and Northern Jordan. Arab World Geographer, 5, 265-290.

[9] Central Water Authority: Hydrological Division (1966) Floods in Southern Jordan on 11 March 1966. Unpublished Report, Amman.

[10] Schick, A. (1971) A Desert Flood: Physical Characteristics, Effect on Man, Geomorphic Significance, Human Adaptation: A Case Study in the Southern Arabia Watersheds. Jerusalem Studies of Geography, 2, 91-155.

[11] Schick, A. (1988) Hydrologic Aspects of Floods in Extreme Arid Environments. In: Baker, V., Kochel, R. and Patton, P., Eds., Flood Geomorphology, Wiley, New York, 189-203.

[12] Schick, A., Grodek, T. and Wolman, G. (1999) Hydrologic Processes and Geomorphic Constraints on Urbanization of Alluvial Fan Slopes. Geomorphology, 31, 325-335. https://doi.org/10.1016/S0169-555X(99)00085-9

[13] Murphy, B. (2010) Hydrologic Analysis for a Hyper-Arid Region in the Middle East. In: Potter, J.W. and Frevert, D.K., Eds., Watershed Management. Innovations in Watershed Management under Land Use and Climate Change, ASCE, Reston, 
1238-1247. https://doi.org/10.1061/41143(394)111

[14] Al-Qudah, K.A. (2011) Floods as Water Resource and as a Hazard in Arid Regions: A Case Study in Southern Jordan. Journal of Civil Engineering, 5, 148-161.

[15] Farhan, Y. and Anbar, A. (2014) Fragile Landscape: Impact and Consequences of May 2014 Flash-Flood Disaster in the Aqaba Area, Southern Jordan. Research Journal of Environmental Earth Sciences, 6, 451-465.

[16] Al-Sherideh, M.S., Malkawi, A., Al-Hamdan, H. and Abdulrahamn, N. (2000) Evaluating Sediment Yield at King Talal Reservoir from Landslides along the Irbid-Amman Highway. Engineering Geology, 56, 361-372. https://doi.org/10.1016/S0013-7952(99)00119-2

[17] Al-Ansari, N. and Knutsson, S. (2010) Reduction of the Storage Capacity of Two Small Reservoir in Jordan. Journal of Earth Sciences and Geotechnical Engineering, 2, 13-37.

[18] Ijam, A. and Tarawneh, E. (2012) Assessing of Sediment Yield for Wala Dam Catchment Area in Jordan. European Water, 38, 43-58.

[19] Ijam, A. and Al-Mahamid, M. (2012) Predicting Sedimentation at Mujib Dam Reservoir in Jordan. Jordan Journal of Civil Engineering, 6, 448-463.

[20] Farhan, Y., Zerqat, D. and Farhan, I. (2013) Spatial Estimation of Soil Erosion Risk Using RUSLE Approach, RS and GIS Techniques: A Case Study of Kufranja Watershed, Northern Jordan. Journal of Water Resources and Protection, 5, 1247-1261. https://doi.org/10.4236/jwarp.2013.512134

[21] Farhan, Y. and Nawaishe, S. (2015) Spatial Assessment of Soil Erosion Risk Using RUSLE and GIS Techniques. Environmental Earth Sciences, 74, 4649-4669. https://doi.org/10.1007/s12665-015-4430-7

[22] Farhan, Y., Zreqat, D. and Anbar, A. (2015) Assessing Farmers' Perception of Soil Erosion Risk in Northern Jordan. Journal of Environmental Protection, 6, 867-884. https://doi.org/10.4236/jep.2015.68079

[23] Dabbas, I. (1994) Soil Erosion Measurement in the Salt Area, Jordan. M.Sc. Thesis, University of Jordan, Amman.

[24] Ananzeh, A. (1986) Sediment Yield of Wadi Kufranja Basin. M.Sc. Thesis, University of Jordan, Amman.

[25] Beni Taha, Q. (2004) Soil Erosion in Jerash Area. M.Sc. Thesis, University of Jordan, Amman.

[26] Jawabreh, A. (1995) Soil Erosion Measurements in the Muwagar Area, Jordan. M.Sc. Thesis, University of Jordan, Amman.

[27] Al-Hamdan, A. (1996) Soil Erosion Measurements in the Azraq Area, Jordan. M.Sc. Thesis, University of Jordan, Amman.

[28] Al-Shabatat, A. (2005) Environmental Deterioration and Land Management in the Petra-Showbak Area, Jordan. Ph.D Thesis, University of Jordan, Amman.

[29] Fahran, Y., Anbar, A., Al-Shaikh, N. and Mousa, R. (2017) Prioritization of Semi-Arid Agricultural Watershed Using Morphometric and Principal Component Analysis, Remote Sensing, and GIS Techniques, the Zerqa River Watershed, Northern Jordan. Agricultural Sciences, 8, 113-148. https://doi.org/10.4236/as.2017.81009

[30] Wischmeier, W.H. (1959) A Rainfall Erosive Index for a Universal Soil-Loss Equation. Soil Science Society of America Journal, 23, 246-249. https://doi.org/10.2136/sssaj1959.03615995002300030027x

[31] Babu, R., Tejwani, K.G., Agarwal, M.C. and Bhusan, L.S. (1978) Distribution of 
Erosion Index and Iso-Erodent Map of India. Indian Journal of Soil Conservation, 6, 1-12.

[32] Singh, G., Rambabu, V. and Chandra, S. (1981) Soil Loss Prediction Research in India. Bulletin No. T-12/D9, Central Soil and Water Conservation Research Training Institute, Dehradun.

[33] Park, S., Oh, C., Jeon, S., Jung, H. and Choi, C. (2011) Soil Erosion Risk in Korean Watersheds, Assessed Using the Revised Universal Soil Loss Equation. Journal of Hydrology, 399, 263-273. https://doi.org/10.1016/j.jhydrol.2011.01.004

[34] Kim, J.H., Kim, K.T. and Lee, H.J. (2009) Analysis of Korea Soil Loss and Hazard Zone. Journal of Geographic Information System of Korea, 17, 261-268. (In Korean)

[35] Rernard, K.G., Foster, G.R, Weesies, G.A., Mc Cool, D.K. and Yoder, D.C. (1997) Predicting Soil Erosion by Water: A Guide to Conservation Planning with Revised Universal Soil Loss Equation (RUSLE). Agricultural Handbook No. 703, USAD-ARS, Washington DC.

[36] Lee, J.H. and Heo, J.-H. (2011) Evaluation of Estimation Methods for Rainfall Erosivity Based on Annual Precipitation in Korea. Journal of Hydrology, 409, 30-48. https://doi.org/10.1016/j.jhydrol.2011.07.031

[37] Wischmeier, W.H. and Smith, D.D. (1978) Predicting Rainfall Erosion Losses: A Guide to Conservation Planning. USDA, Washington DC.

[38] Jung, P., Ko, M., Im, J., Um, K. and Choi, D. (1983) Rainfall Erosion Factor for Estimating Soil Loss. Korean Journal of Soil Science and Fertilizer, 16, 112-118.

[39] Lo, A., El-Swaify, S.A., Dangler, E.W. and Shinsiro, L. (1985) Effectiveness of EI 30 as an Erosivity Index in Hawaii. Soil Erosion and Conservation. In: El-Swaify, S.A., Moldenhauer, W.C. and Lo, A., Eds., Soil Erosion and Conservation, Soil Conservation Society of America, Ankeny, 384-392.

[40] Goovaerts, P. (1999) Using Elevation to Aid the Geostatistical Mapping of Rainfall Erosivity. CATENA, 34, 227-242. https://doi.org/10.1016/S0341-8162(98)00116-7

[41] El-Swaify, S.A., Arsyad, S. and Krishnarajah, P. (1983) Soil Erosion by Water. In: Doerhoefer, G., Ed., The Handbook on Natural Systems Information for Planners, MacMillan, New York, 99-161.

[42] Eltaif, N.I., Gharaibeh, M.A., Al-Zaitawi, F. and Alhamad, M.N. (2011) Approximation of Rainfall Erosivity Factors in North Jordan. Pedosphere, 20, 711-717. https://doi.org/10.1016/S1002-0160(10)60061-6

[43] Olivera, P.T.S., Alves, S.T., Rodrigues, D.B.B. and Panachuki, E. (2011) Erosion Risk Mapping Applied to Environmental Zoning. Water Resources Management, 25, 1021-1036. https://doi.org/10.1007/s11269-010-9739-0

[44] Olivera, P.T.S., Rodrigues, D.B.B.A., Sobrinho, T., Carvalho, D.F. and Panachuki, E. (2011b) Spatial Variability of the Rainfall Erosive Potential in the State of Mato Grosso do Sul, Brazil. Agricultural Engineering, 32, 69-79.

[45] Oliveira, P.T.S., Wendland, E. and Nearing, M.A. (2012) Rainfall Erosivity in Brazil: A Review. CATENA, 100, 139-147. https://doi.org/10.1016/j.catena.2012.08.006

[46] Diodato, N., Ceccarelli, M. and Bellocchi, G. (2008) Decadal and Century-Long Changes in the Reconstruction of Erosive Rainfall Anomalies in a Mediterranean Fluvial Basin. Earth Surface Processes and Landforms, 33, 2078-2093. https://doi.org/10.1002/esp.1656

[47] Stocking, M.A. and Elwell, H.A. (1976) Rainfall Erosivity over Rhodesia. Transaction of the Institute of British Geographers, 1, 231-245. 
https://doi.org/10.2307/621986

[48] Renard, K.G. and Fremund, J. (1994) Using Monthly Precipitation Data to Estimate the $R$-Factor in the Revised USLE. Journal of Hydrology, 157, 287-306.

https://doi.org/10.1016/0022-1694(94)90110-4

[49] Diodato, N. (2004) Estimating RUSLE's Rainfall Factor in the Part of Italy with a Mediterranean Rainfall Regime. Hydrology and Earth System Science, 8, 103-107. https://doi.org/10.5194/hess-8-103-2004

[50] Angulo-Martinez, M. and Begueria, S. (2009) Estimating Rainfall Erosivity from Daily Precipitation Records: A Comparison among Methods Using Data from the Ebro Basin (NE Spain). Journal of Hydrology, 379, 111-121. https://doi.org/10.1016/j.jhydrol.2009.09.051

[51] Zhu, M. (2015) Soil Erosion Assessment Using USLE in the GIS Environment: A Case Study in the Danjiangkou Reservoir Region China. Environmental Earth Sciences, 73, 7899-7908. https://doi.org/10.1007/s12665-014-3947-5

[52] Tang, Q., Xu, Y., Bennett, S.J. and Yang, L. (2015) Assessment of Soil Erosion Using RUSLE and GIS: A Case Study of the Yangou Watershed in the Loess Plateau, China. Environmental Earth Sciences, 73, 1715-1724. https://doi.org/10.1007/s12665-014-3523-Z

[53] Lazzari, M., Gioia, D., Piccarreta, M., Danese, M. and Lanorate, A. (2015) Sediment Yield and Erosion Rate Estimation in the Mountain Catchments of the Camastra Artificial Reservoir (Southern Italy): A comparison Between Different Empirical Methods. CATENA, 127, 323-339. https://doi.org/10.1016/j.catena.2014.11.021

[54] Chen, P. and Lian, Y. (2016) Modeling of Soil Loss and Its Impact Factors in the Guijiang Karst River Basin in Southern China. Environmental Earth Sciences, 75, 352.

[55] Millward, A. and Mersey, J.E. (1999) Adapting the RUSLE to Model Soil Erosion Potential in a Mountainous Tropical Watershed. CATENA, 38, 109-129. https://doi.org/10.1016/S0341-8162(99)00067-3

[56] Van der Knijiff, J.M., Jones, T.J.A. and Montanarella, L. (2000) Soil Erosion Risk Assessment in Italy. European Commission-European Soil Bureau.

[57] Lin, C.Y., Lin, W.T. and Chou, W.C. (2002) Soil Erosion Prediction and Sediment Yield Estimation: The Taiwan Experience. Soil and Tillage Research, 68, 143-152. https://doi.org/10.1016/S0167-1987(02)00114-9

[58] Orori, F., De Bonis, P. and Grauso, S. (2006) Soil Erosion Prediction at the Basin Scale Using the Revised Universal Soil Loss Equation (RUSLE) in a Catchment of Sicily (Southern Italy). Environmental Geology, 50, 1129-1140. https://doi.org/10.1007/s00254-006-0286-1

[59] Saba, M., De Pauw, E. and Goebel, W. (2012) Jordan Climate Maps: Historical and Current. International Center for Agricultural Research in the Dry Areas (ICARDA).

[60] Fisher, W., Bowen-Jones, H., Alkinson, K., Beaumont, P., Smith, K. and Stevens, J. (1969) Soil and Land Potential Survey of the Highlands of Northwest Jordan. University of Durham, Durham.

[61] Burdon, D. (1959) Handbook of the Geology of Jordan. Benham, Colchester.

[62] Bender, F. (1975) Geology of the Arabian Peninsula: Jordan. United States Geological Survey Professional Paper 560-I, Washington DC.

[63] Eiumnoh, A. (2000) Integration of Geographic Iinformation System (GIS) and Satellite Remote Sensing (SRS) for Watershed Management. Food and Fertilizer 
Technology Center, Taipei. http://www.fftc.agnet.org/library.phpfunc=view\&id=20110809090940\&type_id $=5$

[64] Hartcher, M.G., Post. D.A. and Kinsey-Henderson, A.E. (2005) Uncertainty in Modeling the Sources and Sinks of Suspended Sediment in the Mae Chaem Catchment, Thailand. Proceedings of the 2005 International Conference of Simulating and Modeling (SIMMOD), Bangkok. http://www.mssanz.org.au/simmod05/papers/C5-01.pdf

[65] Sulistioadi, Y.B. (2004) Identification of High Conservation Value Forest (HCVF) Related to Soil and Water Conservation: The Use of Remote Sensing and GIS to Support Forest Certification in Indonesia. M.Sc. Thesis, International Institute for Geo Information Science and Earth Observation, Enschede, Netherlands.

[66] Thang, C.C., Euimnoh, A., Shivakoti, G.P. and Clemente, R. (2005) Spatial Modeling for Land Degradation Assessment Using Remotely Sensed Data and Geographic Information System: A Case Study of Daungnay Watershed, Magway District, Myanmar. Conference Proceedings: Map Asia 2005.

[67] Blanco, A.C. and Nadaoka, K. (2006) A Comparative Assessment of Estimation of Relative Soil Erosion Rates and Patterns in Laguna Lake Watershed Using Three Models: Towards Development of an Erosion Index System for Integrated Watershed-Lake Management. Proceedings of the Symposium on Infrastructure Development and the Environment, Quezon City, 7-8 December 2006, 221-231.

[68] Ghosh, K., De Kumar, S., Bandyopadhyay, S. and Saha, S. (2013) Assessment of Soil Loss of the Dhalai River Basin, Tripura, India Using USLE. International Journal of Geosciences, 4, 11-23. https://doi.org/10.4236/ijg.2013.41002

[69] Ministry of Water and Irrigation (MWI) (2015) Unpublished Rainfall Records, Amman.

[70] Sharon, D. (1972) The Spottiness of Rainfall in a Desert Area. Journal of Hydrology, 17, 161-175. https://doi.org/10.1016/0022-1694(72)90002-9

[71] Schick, A. (1974) Alluvial Fans and Desert Roads: A Problem in Applied Geomorphology. Akademie der Wissenschaften in Gottingen. Journal of Mathematical Physics, 29, 418-425.

[72] Abu Hussein, S.A. (1994) The Effect of the Red Sea Trough on Jordan Climate During the Fall and Spring Seasons. M.Sc. Thesis, University of Jordan, Amman.

[73] Shehadeh, N. (1990) The Climate of Jordan. Dar Al-Basheir Publications, Amman. 